\title{
Dating minerals by ID-TIMS geochronology at times of in situ analysis: selected case studies from the CPGeo-IGc-USP laboratory
}

\author{
ClÁudia R. PASSARELli, Miguel A.S. BASEI, OSWALdo SIGA JR., KEI SATO, \\ WALTER M. SPROESSER and VASCO A.P. LOIOS \\ Instituto de Geociências, USP, Rua do Lago, 562, 05508-080 São Paulo, SP, Brasil \\ Manuscript received on January 17, 2008; accepted for publication on July 14, 2008; \\ contributed by MIGUEL A.S. BASEI*
}

\begin{abstract}
Since 1964, the Center for Geochronological Research - CPGeo, one of the interdepartmental centers of the Instituto de Geociências (IG) of São Paulo University, has developed studies related to several geological processes associated with different rock types. Thermal Ionization Mass Spectrometry Isotopic Dilution (ID-TIMS) has been the technique widely used in the CPGeo U-Pb Laboratory. It provides reliable and accurate results in age determination of superposed events. However, the open-system behavior such as $\mathrm{Pb}$-loss, the inheritance problem and metamictization processes allow and impel us to a much richer understanding of the power and limitations of U-Pb geochronology and thermochronology. In this article, we present the current methodology used at the CPGeo-IGc-USP U-Pb laboratory, the improvements on ID-TIMS method, and report high-precision $\mathrm{U}-\mathrm{Pb}$ data from zircon, monazite, epidote, titanite, baddeleyite and rutile from different rock types of several domains of the Brazilian south-southeast area, Argentina and Uruguay.
\end{abstract}

Key words: U-Pb ID-TIMS methodology, U-Pb geochronology of accessory minerals, CPGeo-IGc-USP U-Pb laboratory.

\section{INTRODUCTION}

The Centro de Pesquisas Geocronológicas (Center for Geochronological Research - CPGeo) is one of the interdepartmental centers of the Instituto de Geociencias (IG) of São Paulo University. Since 1964, the Interdepartmental Laboratory of Isotopic Geology focus the study of the Earth's geologic processes, dealing with themes such as plate tectonics, plutonism, volcanism, sedimentary rocks, tectono-thermal evolution, and more recently environmental studies.

CPGeo gathers modern laboratories installed in an area of $1080 \mathrm{~m}^{2}$ and is equipped with seven mass spectrometers for radiogenic and stable isotope analysis. Among the up-to-date pieces of equipment there are three solid-source mass spectrometers (two VG 354

\footnotetext{
*Member Academia Brasileira de Ciências Correspondence to: Cláudia Regina Passarelli E-mail: crpass@usp.br
}

and a Finnigan MAT 262) and two gaseous-source (a MAP 215 Ar-Ar and a Europa GEO 20/20). An internal network (GEOCRON) links all laboratories. Soon Neptuno, Triton, Shrimp II and Noblesse will be added to the laboratory.

In the U-Pb Laboratory of the CPGeo-IGc-USP, the isotopic dilution method ID-TIMS - Isotope Dilution Thermal Ionization Mass Spectrometry - is used, as well as in other laboratories in Brazil (e.g. Pará-Iso Isotope Geology Laboratory-UFPA, Krymsky et al. 2007). The method is considered one of the most precise among the isotopic techniques available for $\mathrm{U}-\mathrm{Th}-\mathrm{Pb}$ geochronology of accessory minerals, because it is relative insensitive to chemical yields or mass spectrometric sensitivity (Parrish and Noble 2003), and is therefore largely used by the scientific community.

According to Kosler and Sylvester (2003) the in situ U-Pb geochronology was introduced $c a$. two dec- 
ades ago with the development of the high-resolution, secondary ion mass spectrometry technique (SIMS or SHRIMP).

TIMS analyses, comparatively to SIMS analyses, have the advantage of producing high-precision U-Pb data, being specifically important when dating superposed events or even a single crystal, in order to define crystallization ages. However, ion microprobe analysis has the advantage of higher spatial resolution, allowing analysis of complex zoned crystals and fast data acquisition.

Countless works in the literature show the pros and cons of TIMS and SIMS, which are, in a broad sense, complementary techniques and the application of one or another will depend on the geological problem to be solved. There will be situations for which SIMS or LA-ICP-MS is more appropriate or advantageous than TIMS and vice-versa.

The article presents the U-Pb ID-TIMS methodology now in routine at the CPGeo-IGc-USP U-Pb laboratory and discusses the success of the geological application of the method for several minerals as zircon, monazite, titanite, rutile, epidote and baddeleyite.

\section{GENERAL INFORMATION}

The U-Pb method is one of the most precise to obtain crystallization ages of igneous rocks as well for the chronological identification of superposed metamorphism in polycyclic regions. The routine in the laboratory starts with the separation and selection of populations of accessory minerals under a stereoscope that is coupled with an imaging system.

The total blank values of the U-Pb laboratory have been of $c a .5$ picograms $\mathrm{Pb}$, since the last years, reaching up to 3 picograms (until November 2007). The use of spike ${ }^{205} \mathrm{~Pb} /{ }^{235} \mathrm{U}$ (mixed ${ }^{205} \mathrm{~Pb} /{ }^{235} \mathrm{U}$ tracer) since February 1999 , combined with the (chemical and mechanical) crystal abrasion process and the low laboratory blank values, has enabled the determination of U-Pb ages of zircon fractions of a few micrograms from Cretaceous and even Tertiary rocks and the use of a single crystal from Neoproterozoic rocks.

The laboratory is divided into different isolated sectors. The external areas correspond to a computing room, where the data are treated and processed, and a separa- tion room, where final heavy mineral fractions are processed by a Frantz electromagnetic separator.

The internal areas are equipped with a non-stop insufflating system that serves three rooms. A mechanic abrasion system and an exhaustion hood are installed in the first room, where materials coming from the weighing room are decontaminated. The weighing room is equipped with weighing machines and stereoscopes coupled with imaging systems. The third is certified and qualified as a "clean room" (a positive pressure room equipped with a vertical unidirectional airflow hood and Clean Box classified as ISO 05), where chemical digestion and material deposition on filament take place, followed by mass spectrometer analysis.

\section{THE U-Th-Pb METHOD}

\section{PrinciPles OF THE U-Th-PB Method}

The $\mathrm{U}-\mathrm{Th}-\mathrm{Pb}$ method is based on the $\mathrm{U}$ and $\mathrm{Th}$ radioactive decay to stable $\mathrm{Pb}$ isotopes. Uranium occurs in nature as radiogenic ${ }^{238} \mathrm{U},{ }^{235} \mathrm{U}$ and ${ }^{234} \mathrm{U}$ isotopes, whereas thorium mainly occurs as ${ }^{232} \mathrm{Th}$. Lead exists as radiogenic ${ }^{206} \mathrm{~Pb},{ }^{207} \mathrm{~Pb}$ and ${ }^{208} \mathrm{~Pb}$ and non-radiogenic ${ }^{204} \mathrm{~Pb}$ isotopes, the latter also referred to as common $\mathrm{Pb}$.

This is a special isotopic system because it involves three distinct decay systems, where $\mathrm{U}$ and $\mathrm{Th}$ isotopes decay to stable $\mathrm{Pb}$ isotopes (Faure and Mensing 2005):

$$
\begin{aligned}
& { }^{238} \mathrm{U} \rightarrow{ }^{206} \mathrm{~Pb}+8 \alpha+6 \beta-+\mathrm{Q} \\
& { }^{235} \mathrm{U} \rightarrow{ }^{207} \mathrm{~Pb}+7 \alpha+4 \beta-+\mathrm{Q} \\
& { }^{232} \mathrm{Th} \rightarrow{ }^{208} \mathrm{~Pb}+6 \alpha+4 \beta-+\mathrm{Q}
\end{aligned}
$$

The alpha particles $(\alpha)$ are He nuclei (two protons and two neutrons). The beta radiation $(\beta)$ represents an electron. $\mathrm{Q}$ is the energy liberated in the disintegration process and is originated by the difference of mass between the parent nucleus and the disintegration products.

The $\mathrm{U}$ and $\mathrm{Th}$ isotopes have well defined half-lives and disintegration constants $\lambda$ (Steiger and Jäger 1977 Table I), being $\lambda$ the probability of a nuclide to disintegrate spontaneously per time unit. Each nuclide has its own $\lambda$, which is a function of the velocity of the process. The half-life of an isotope is the time necessary for half of its mass to disintegrate and depends on how unstable an isotope is, which is a direct function of $\lambda$. 
The radiometric ages can be mathematically expressed by negative exponential equations:

$$
\begin{aligned}
& \mathrm{Pb}^{206}=\mathrm{U}^{238} \times\left(\mathrm{e}^{\lambda t}-1\right) \\
& \mathrm{Pb}^{207}=\mathrm{U}^{235} \times\left(\mathrm{e}^{\lambda t}-1\right)
\end{aligned}
$$

Time t can be expressed by:

$$
t=\frac{1}{\lambda}\left\{\ln \left[\frac{1+\left(\frac{\mathrm{Pb}^{206}}{\mathrm{~Pb}^{204}}\right)_{\mathrm{t}}-\left(\frac{\mathrm{Pb}^{207}}{\mathrm{~Pb}^{204}}\right)_{0}}{\left(\frac{\mathrm{U}^{238}}{\mathrm{~Pb}^{204}}\right)}\right]\right\}
$$

where $\mathrm{Pb}^{204}$ is the common $\mathrm{Pb}$ of the material analyzed plus $\mathrm{Pb}$ present in the laboratory. By analogy, $\mathrm{U}^{235}$ and $\mathrm{Pb}^{207}$ are obtained. When compared to other methods, the $\mathrm{U}-\mathrm{Pb}$ geochronologic system is the only one able to offer two radiometric chronometers for a pair of elements of a single material. Besides, the $\mathrm{Pb}^{207} / \mathrm{Pb}^{206}$ age can also be calculated.

Ahrens (1995) and Wetherill (1956) established the concept of Concordia Curve, which represents the geometric locus of points of concordant ages, obtained by the two $\mathrm{U}^{238} / \mathrm{Pb}^{207}$ chronometers and consequently $\mathrm{Pb}^{207} / \mathrm{Pb}^{206}$. If an analytical point does not plot on the Concordia Curve, the ages are no more concordant. Then the results yielded by each chronometer are different, thus characterizing a discordance. The line that contains the discordant points is called Discordia.

The upper intersection of the discordia line with the concordia curve characterizes the time of crystallization for the minerals analyzed. Interpretations exist for the lower intercept that relate it to either an episodic or a continuous loss of $\mathrm{Pb}$. The episodic $\mathrm{Pb}$ loss is usually associated with a tectono-metamorphic event and it will only be geologically meaningful if it is supported by another geologic evidence confirmed by another methodology (Dickin 1995). Additionally, the more concordant the analytical points the more reliable the age defined by the upper intercept will be (Mezger and Krogstad 1997).

Primary zircons lose $\mathrm{Pb}$ by diffusion (Cherniak and Watson 2000). During a thermal event, zircons will lose $\mathrm{Pb}$ while they recrystallize. This can result in meaningless ages for the upper and lower intercepts (Mezger and Krogstad 1997). The continuous $\mathrm{Pb}$ diffusion is frequently associated with metamictization processes that reflect instabilities in the zircon crystalline net.
Another very common aspect of the zircon $\mathrm{U}-\mathrm{Pb}$ analysis is related to inheritance, as zircons preserve the isotopic memory of primeval rocks in their nuclei, even if affected by high-grade metamorphism. This can limit the applicability of the method, especially when the aim of the study is to establish the age of crystallization of a rock. Granitic rocks may contain newly-formed zircons on old nuclei (which preserve the primeval isotopic characteristics). When these crystals are analyzed, the analytical points plot along a Discordia, being the upper intercept with the Concordia Curve the (protolith) primary crystallization age, and the lower intercept, the zircon recrystallization age. This is a simplistic interpretation and the researcher must have in mind that metamictization ( $\mathrm{Pb}$ loss) may happen during the growth of a zircon crystal, leading to wrong conclusions (Basei et al. 1995). Therefore the use of other techniques that involve the U-Pb system is mandatory, as well as other methodologies (Muir et al. 1994, Dickin 1995, Roddick and Bevier 1995).

\section{Application of the U-Th-PB Method}

Most of the rock-forming minerals have very low $U$ and Th contents. In contrast, these elements are reasonable concentrated in accessory minerals, such as zircon, monazite, baddeleyite, titanite, rutile, apatite, allanite, xenotime and perovskite.

The occurrence of U-bearing minerals in most of the acid, intermediate and sometimes basic rocks appoints the $\mathrm{U}-\mathrm{Pb}$ geochronologic system as one of the most precise and efficient methods to determine the crystallization ages of igneous rocks and also to chronologically identify a series of superposed geologic events that characterizes the history of a region.

The U-Pb method constitutes an important tool to solve complex geologic problems, not only because it can be applied to exceptionally resistant minerals (remarkably zircon), but also for the possibility of dating certain accessory minerals that can provide ages for late-crystallization events.

The application of the method to more than one accessory mineral favors the study of polycyclic terranes because each mineral has its own behavior in relation to varying P-T conditions. Another important application is related to the resistance of these minerals to weath- 
ering, allowing the use of the technique for dating of detrital minerals of sedimentary rocks.

Zircon is widely used because of their physical and chemical properties: resistance to weathering, $\mathrm{U}$ contents, $\mathrm{Pb}$ incompatibility (most of it is radiogenic $\mathrm{Pb}$ ), and geochronological stability: even under intense metamorphic conditions, able to isotopically re-homogenize other radiometric chronometers, zircons can preserve primeval records (Basei et al. 1995). Usually zircon registers a very complex growth history at closing temperatures $\left(T_{c}\right)$ of the U-Th- $\mathrm{Pb}$ system above $900^{\circ} \mathrm{C}$ (Lee et al. 1997, Cherniak and Watson 2003).

The SIMS technique when coupled with cathodoluminescence images gives the possibility to obtain information about inherited nuclei and metamorphic overgrowths, and the results can be used to identify and distinguish protoliths and geologic processes in which zircon was formed or modified.

Minerals of lower $T_{c}$ such as titanite, allanite, rutile, apatite or even monazite, have contributed to the determination of the thermal history of rocks belonging to terranes of complex tectono-metamorphic history, complementing the interpretation of zircon $\mathrm{U}-\mathrm{Pb}$ data.

Titanite and monazite frequently yield concordant ages (analytical points on the Concordia Curve), which can be identical or younger than those obtained from zircon. In the second case, the data can indicate the ages of superposed events in polycyclic areas, provided that temperatures of the thermal overprint be constrained between 550 and $750^{\circ} \mathrm{C}$ (Pidgeon et al. 1996, Zhang and Schärer 1996).

Titanite has a relatively high $T_{c}$, which allows the dating of metamorphic growth at least in high amphibolite facies (Cherniak 1993, Scott and St.-Onge 1995, Frost et al. 2000). Titanite is less susceptible than zircon to $\mathrm{Pb}$ losses at low temperatures because of recrystallization that resets a consequent annealing of the damages caused by radiation. On the other hand, titanite ages can indicate either a localized low-grade metamorphic or hydrothermal event, such as regional cooling (Mezger et al. 1993, Corfu and Easton 1997, Praamsma et al. 2000). Titanite also reacts to metamorphism, reflecting overprint episodes. Metamorphic titanites reveal a complex $\mathrm{U}-\mathrm{Pb}$ systematics that sometimes contain information on the whole metamorphic history of the rock (Frost et al. 2000).

Monazite is found in relatively Ca-poor and Al-rich rocks. It is widely used to determine the ages of magmatic and metamorphic events (Parrish 1990). In most cases, monazite $\mathrm{U}-\mathrm{Pb}$ ages are concordant (Corfu 1988, Simpson et al. 2000). However, discordant ages are not rare and result from mixing of monazite populations that crystallized at distinct times (Bertrand et al. 1993), isotopic inheritance (Rubatto et al. 2001), or even $\mathrm{Pb}$ loss (Suzuki et al. 1994). Closing temperatures have been suggested by several authors, between $720-750^{\circ} \mathrm{C}$ (Copeland et al. 1988), $725 \pm 25^{\circ} \mathrm{C}$ (Parrish 1990, Hawkins et al 1996), and above $750^{\circ} \mathrm{C}$ (Spear and Parrish 1996, Dahl 1997, Cherniak et al. 2004, Rubatto et al. 2001). It has been also demonstrated that the monazite $\mathrm{U}-\mathrm{Pb}$ system is reset by recrystallization rather than by $\mathrm{Pb}$ diffusion (Zhu et al. 1997). It is a very interesting mineral once it records the metamorphic history and even the metamorphic peak. Recrystallization mechanisms such as dissolution/reprecipitation can cause disturbance in the monazite $\mathrm{U}-\mathrm{Th}-\mathrm{Pb}$ system, where the $\mathrm{Pb}$ diffusion is extremely slow relative to other minerals (Cherniak et al. 2004). Due to the high Th content, there is a significant percentage of short-life ${ }^{230} \mathrm{Th}$ isotope of the $\mathrm{U}$ decaying series that subsequently decays to ${ }^{206} \mathrm{~Pb}$, causing a ${ }^{206} \mathrm{~Pb}$ excess (Ludwig 1977) and therefore reverse or negative discordances (Schärer 1984, Parrish 1990, Foster et al. 2000).

Baddeleyite mainly occurs in alkaline mafic and ultramafic rocks as well as in pegmatites, formed by pneumatolitic processes. In amphibolite facies metamorphic zircon can substitute or overgrow this mineral, in this last case, crystallization (baddeleyite) and metamorphism (zircon) ages can be obtained. Uranium concentrations in baddeleyite vary in the $200-2000 \mathrm{ppm}$ interval. It also contains low contents of $\mathrm{Th}$ and common $\mathrm{Pb}$, and $\mathrm{Pb}$ loss or isotopic inheritance is rarely observed. All these aspects suggest that baddeleyite can be completely reset, yielding concordant $\mathrm{U}-\mathrm{Pb}$ ages (Corfu and Andrews 1986). It is an ideal candidate for isotopic dilution dating (Heaman and LeCheminant 1993, 2000).

Allanite belongs to the epidote group and its Th-REE contents are high. It is frequently used for $\mathrm{U}-\mathrm{Th}-\mathrm{Pb}$ dat- 
ing (Parrish et al. 1992, Davis et al. 1994, 1997, Corfu and Easton 2000, Poitrasson 2002, Romer and Xiao 2005). However, high common $\mathrm{Pb}$ contents (Poitrasson 2002), ${ }^{206} \mathrm{~Pb}$ excess originated from ${ }^{230} \mathrm{Th}$ decay, which causes reverse discordance (Corfu and Easton 2000), and chemical inheritance (Romer and Siegesmund 2003) can make the U-Pb analyses problematic, yielding ages without geologic meaning. Some successful applications are although reported (Barth et al. 1994, Davis et al. 1994, Catlos et al. 2000, Poitrasson 2002). Allanite U-Pb ages together with the petrographic support can provide the time of the peak metamorphism (Kim et al. 2007).

Rutile is the most common $\mathrm{TiO}_{2}$ polymorph, and yielded precise U-Pb ages (e.g., Schärer et al. 1986, Corfu and Andrews 1986, Mezger et al. 1989, 1991, Schandl et al. 1990, Wong et al. 1991, Davis et al. 1994, Davis 1997). It is a common metamorphic mineral, but is also found in igneous rocks. It is used as a low-temperature geochronometer, yielding information on metamorphic cooling (e.g., Mezger et al. 1989, 1991, Heaman and Parrish 1991, Miller et al. 1996, Davis 1997, Timmermann et al. 2004). However, the results obtained by Cherniak (2000) pose questions on the use of rutile as a low-temperature geochronometer. Rutile closing temperatures, between 400 and $500^{\circ} \mathrm{C}$ (Mezger et al. 1989, 1991), are among the lowest of the U-Pb system, and were determined by empirical $\mathrm{T}_{\mathrm{c}}$ calibrations versus the temperature-time history of the North-American metamorphic terranes (Mezger et al. 1989). Experimental studies have indicated that $\mathrm{T}_{\mathrm{c}}$ for $\mathrm{Pb}$ diffusion in rutile is considerable higher and that rutile has a high activation energy for $\mathrm{Pb}$ diffusion, therefore being resistant to later isotopic resetting. Such studies have indicated that rutile can be used as a high-temperature geochronometer, also being an alternative for monazite or titanite. Thus, it is a mineral that can provide additional geochronological information on high-temperature polymetamorphic terranes and on later cooling (Vry and Baker 2006).

\section{TECHNIQUES USED AT CPGeo}

Procedures at the Mineral Separation LABORATORY

CPGeo has a Mineral Separation Laboratory (MSL) adapted for all isotopic methodologies (Ar-Ar, K-Ar,
$\mathrm{Rb}-\mathrm{Sr}, \mathrm{Sm}-\mathrm{Nd}, \mathrm{Pb}-\mathrm{Pb}, \mathrm{U}-\mathrm{Pb}$ and stable isotopes) and a large-sized deposit of hand specimens collected in the field for geochronological studies.

\section{Mineral concentration for U-Pb analysis}

The hand specimens collected in the field are manually broken in fragments of approximately $5 \mathrm{~cm}$ of diameter (Fig. 1A), which are processed in a jaw crusher (Fig. 1B). After crushing (Fig. 1C) the less than $0.5 \mathrm{~cm}$-sized material is ground in a disc mill (Fig. 1D), which gradually reduces the size of the crushed material to an extremely fine fraction. The resulting material is mechanically sieved (Fig. 1E) through a sequence of 60, 100 and 250-mesh sieves. Disposable nylon screens are used together with 100 and 250 mesh sieves to avoid contamination. The 60-mesh sieve is cleaned on a light table. The disc mill is used concomitantly with the siever (Fig. $1 \mathrm{E})$. The initial aperture of the disc mill is controlled to avoid pulverization of the material; gradually the discs close and the material is sieved after grinding. The material remaining on 60 - and 100-mesh sieves returns to the disc mill and the material remaining on the 250mesh sieve and at the bottom is collected. The objective of these combined procedures is to obtain the maximum volume possible on 100-250 mesh and fewer than 250 mesh.

Fractions between 100-250 mesh and less than 250 mesh are the most used to obtain concentrations of heavy minerals (zircon, titanite, monazite, allanite, rutile, apatite, amphibole, biotite, etc).

At this step the material is processed using a concentration table or vibrating table (Wiffley Table) (Fig. $1 \mathrm{~F}$ ), which by vibration and water pressure, separates minerals by density. Sulfides, zircon, gold, garnet, monazite, titanite, apatite, among others, are separated from minerals lighter than $2.6 \mathrm{~g} / \mathrm{cm}^{3}$, such as quartz and feldspars. Although the density of biotite is $2.7-3.3 \mathrm{~g} / \mathrm{cm}^{3}$, due to its lamellar habit, it is distributed together with both heavy and light minerals. 'Tracks' of minerals are formed on the table (Fig. 1G), the first one corresponding to the higher concentration of dense minerals, which are collected in a recipient called Caneca 1 . In the following track corresponds the less dense minerals and of lamellar shape (micas) are concentrated and collected in a recipient called Caneca 2 . After the whole sample 
is processed, the materials from Canecas 1 and 2 are soaked in alcohol to avoid oxidation during drying. The largest concentration of minerals for U-Pb dating is in Caneca 1.

After drying, a hand magnet is used to remove highly magnetic minerals such as magnetite and ilmenite from the Caneca 1 concentrate. Another magnetic separation takes place by means of an Isodynamic Frantz (Fig. 1H). Initially the material from Caneca 1 is processed with maximum initial amperage of $0.4 \mathrm{~A}$ and a $10^{\circ}$ lateral and $20^{\circ}$ frontal inclination. The amperage should not exceed $0.4 \mathrm{~A}$ to avoid the loss of certain minerals such as monazite, which has a high magnetic sensitivity. The material processed by the Frantz separator is separated into two fractions: a magnetic concentrate at $0.4 \mathrm{~A}$ (garnet, amphibole, biotite, epidote and pyroxene) and a non-magnetic concentrate at $0.4 \mathrm{~A}$ (quartz, feldspars, apatite, rutile, zircon, badelleyite, monazite, titanite and sulfides). In the Frantz separator these concentrations are distributed along two grooves. In general the mafic minerals tend to be magnetic, whereas the light and translucent minerals are non-magnetic (Fig. 1I).

After this magnetic separation, the non-magnetic material is mixed with dense liquids in an exhaustion hood (Fig. 1J) for mineral selection by density. Firstly, Bromoform $\left(\mathrm{d}=2.81 \mathrm{~g} / \mathrm{cm}^{3}\right)$ is used to eliminate lowdensity minerals such as quartz and plagioclase. The two resulting concentrates, a light $\left(\mathrm{d}<2.81 \mathrm{~g} / \mathrm{cm}^{3}\right)$ and a heavy $\left(\mathrm{d}>2.81 \mathrm{~g} / \mathrm{cm}^{3}\right)$ are soaked in alcohol and dried. The heavy material is then mixed with Methylene Iodide $\left(\mathrm{d}=3.32 \mathrm{~g} / \mathrm{cm}^{3}\right)$, being further separated in two concentrates: light $\left(\mathrm{d}<3.32 \mathrm{~g} / \mathrm{cm}^{3}\right)$ and heavy $\left(\mathrm{d}>3.32 \mathrm{~g} / \mathrm{cm}^{3}\right)$. Both fractions are washed with acetone. The heavy concentrate from the methylene iodide treatment contains minerals of interest, such as zircon, monazite and titanite.

The final purification is again carried out in the Frantz magnetic separator, by varying the amperage according to the minerals of interest present. For zircon concentration an initial amperage of $1.0 \mathrm{~A}$ is applied, usually keeping the $10^{\circ}$ lateral inclination. Besides zircon, apatite and sulfides are concentrated in the nonmagnetic fraction at $1.0 \mathrm{~A}$. The material is then washed with $\mathrm{HNO}_{3} 50 \%$ for the elimination of sulfides. Then the magnetic fraction at $1.0 \mathrm{~A}$ is processed again in the
Frantz separator operating with amperages of $0.5 \mathrm{~A}, 0.6 \mathrm{~A}$ and $0.8 \mathrm{~A}$ in order to separate titanite, monazite and allanite.

\section{Procedures at the U-Pb Laboratory}

At the most external area of the laboratory, the $\mathrm{HNO}_{3}$ washed, non-magnetic fraction at $1.0 \mathrm{~A}$ is once more processed in the Frantz separator using different lateral inclinations $\left(10^{\circ}, 8^{\circ}, 6^{\circ}\right.$, etc. $)$ and keeping amperage and frontal inclination constant. From this technique, known as Split, fractions of different magnetic susceptibilities are obtained with the following denominations: M10, M6, M4 ... M0, M-1, M-2,.. etc for $10^{\circ}, 6^{\circ}$, $4^{\circ} \ldots 0^{\circ},-1^{\circ},-2^{\circ}$, etc.. lateral inclinations, respectively). This is an important process (Krogh 1982a), due to the inverse relationship between magnetic susceptibility and zircon $\mathrm{Pb}$ concentration (Mezger and Krogstad 1997). Low-U zircons lose less $\mathrm{Pb}$ than high-U zircons, due to radiation damage. Additionally, metamict zircons tend to incorporate impurities (e.g. Fe) in their crystalline structure. Splitting furnishes fractions of different magnetic intensities and therefore variable discordances.

In the weighing room, the final purification of each magnetic fraction (preferably the least magnetic M-3, $\mathrm{M}-4$, etc) is carried out manually with needle under the stereoscope. The fractions must contain zircon crystals that are similar in habit, size, color, and that are preferentially free of inclusions or fractures.

Fracture-free crystals are preferentially selected, and a special attempt is also made to avoid inclusions. The selection of titanites must favor darker crystals, because their $\mathrm{U}$ and consequently radiogenic $\mathrm{Pb}$ contents are usually higher.

Depending on the crystal characteristics and the objective of the analysis, mechanical abrasion can be carried out. Crystals are abraded by adding an equivalent quantity of pure pyrite in an abrator coupled with a compressed-air system for approximately 15 minutes (Fig. 2A). The outermost parts, which may contain high common- $\mathrm{Pb}$ contents, are blasted away (Krogh 1982b). The abraded fraction is then taken up with hot $7 \mathrm{~N} \mathrm{HNO}_{3}$ to dissolve the added pyrite. This fraction is washed with mili-Q water in ultrasound equipment.

The volume/density relationship provides the weight of zircon crystals. The volume is estimated us- 


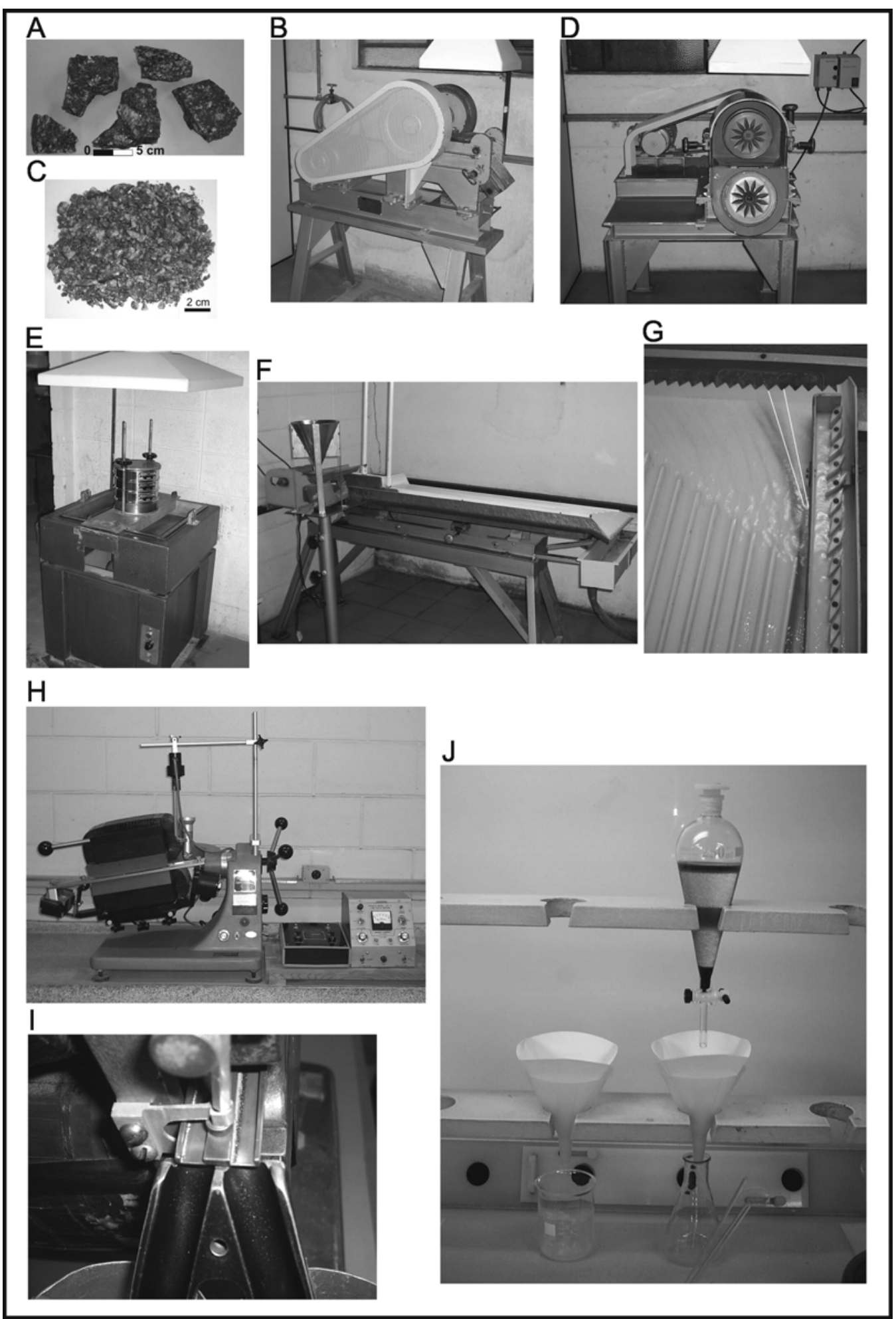

Fig. 1 - Instruments and equipment of the Mineral Separation Laboratory. The MSL for Isotope Geology has the basic equipment for crushing, milling and sieving of rock samples, as well as for mineral separation using Wilfley table, Frantz Isodynamic Separators and heavy liquids. For a detailed explanation, see text. 
ing the imaging system coupled with the stereoscope (Fig. 2B). The total mass required rarely exceeds $50 \mu \mathrm{g}$ for Neoproterozoic samples, the average value usually adopted being $15 \mu \mathrm{g}$ per fraction. It is also common the analysis of a single crystal weighing around $2 \mu \mathrm{g}$. Besides the volume/density relationship, the mass of low- $\mathrm{Pb}$ minerals, such as titanite, rutile and baddeleyite, can be obtained on a high-precision analytical weighing machine (average $100 \mu \mathrm{g}$ ). For monazite, a single crystal usually constitutes each fraction, once the radiogenic $\mathrm{Pb}$ content in monazite is high.

After weighing, the material is washed (chemical abrasion) with $6 \mathrm{~N} \mathrm{HCl}$ and $7 \mathrm{~N} \mathrm{HNO}_{3}$ for the elimination of respectively superficial common $\mathrm{Pb}$ and organic material. The material is further stored in $14 \mathrm{~N}^{-} \mathrm{NO}_{3}$.

Chemical abrasion of zircon crystals starts with $6 \mathrm{~N} \mathrm{HCl}$, with intercalations of plate heating and ultra-

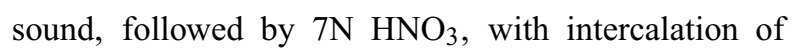
MiliQ water washes. Finally chemical abrasion with $14 \mathrm{~N} \mathrm{HNO}_{3}$ takes place, which is an appropriate solution for further chemical digestion. The same procedure is adopted for other minerals, excepting the plate heating.

The dissolution of mineral samples and separation of the elements of interest, $\mathrm{U}$ and $\mathrm{Pb}$, are carried out in the chemistry clean chemistry laboratory. In order to keep contamination at low levels and make it possible to prepare and analyze small U-Pb samples, the laboratory is built as a clean room with an overpressure of filtered air inside, as detailed previously.

The chemical digestion of zircon, titanite, rutile, allanite and baddeleyite takes place in Teflon beakers using $\mathrm{HF}$ and $\mathrm{HNO}_{3}$ (Fig. 2C). Mixed ${ }^{205} \mathrm{~Pb} /{ }^{235} \mathrm{U}$ tracer $(10 \mu \mathrm{l})$ is added and the beakers are heated to $200^{\circ} \mathrm{C}$ for three days for total mineral dissolution (Fig. 2D). $5 \mu 1$ of mixed ${ }^{205} \mathrm{~Pb} /{ }^{235} \mathrm{U}$ tracer are added to the blank that accompanies the analyses.

Chemical digestion of monazites takes place in 3 $\mathrm{ml}$ screw-top PFA Savillex vials, with the addition of one micro-drop of $\mathrm{HNO}_{3}$ and $7 \mu 1$ of ultra-pure $\mathrm{H}_{2} \mathrm{SO}_{4}$. The vials stand on a hot plate for three days.

After the chemical digestion, the solution is transferred to a 7-ml savillex and dry-evaporated. $6 \mathrm{~N} \mathrm{HCl}$ is added and the savillex stand on a hot plate overnight
(Fig. 2E). The solution is dry-evaporated and dissolved in $3 \mathrm{~N} \mathrm{HCl}$, ready for anion exchange column chemistry.

The U-Pb laboratory of CPGeo uses the Parrish et al. (1987) method of $\mathrm{Pb}-\mathrm{U}$ separation from zircon solution, with modifications.

The columns have $150 \mu 1$ of 400 mesh Eichrom $1 \times 8200$ anion exchange resin approximately, forming a column of settled resin about $1,8 \mathrm{~cm}$ high, previously washed with $6 \mathrm{~N} \mathrm{HCl}$ and MILLIQ water. Separation and purification of $\mathrm{U}$ and $\mathrm{Pb}$ occurs by leaching of other elements using different $\mathrm{HCl}$ concentrations (Fig. 2F). $\mathrm{U}$ and $\mathrm{Pb}$ are collected in MILLIQ water. A drop of $0,25 \mathrm{~N} \mathrm{H}_{3} \mathrm{PO}_{4}$ is added, and after evaporation, it is ready for mass spectrometry. The chemical procedure is summarized in Table I.

TABLE I

Chemical procedure for the extraction of $\mathrm{U}$ and $\mathrm{Pb}$ using microcolumns for zircon, monazite and baddeleyite.

\begin{tabular}{l}
\hline Column and resin washing \\
\hline Add $150 \mu 1$ of 400 mesh Eichrom $1 \times 8200$ resin \\
Wash with $\cong 300 \mu 1$ MiliQ $\mathrm{H}_{2} 0$ \\
Wash with $\cong 300 \mu 1$ $6 \mathrm{~N} \mathrm{HCl}$ \\
Add $120 \mu 13 \mathrm{~N} \mathrm{HCl}$ to condition \\
\hline \hline Add and wash sample \\
\hline Add sample to column \\
Add $90 \mu 13 \mathrm{~N} \mathrm{HCl}$ \\
Add $120 \mu 16 \mathrm{~N} \mathrm{HCl}$ \\
\hline \hline Collect $\mathrm{U}$ and $\mathrm{Pb}$ \\
\hline Replace with $\mathrm{U}$ and $\mathrm{Pb}$ collection 7 -ml savillex vials \\
Add 10 drops $\mathrm{MiliQ} \mathrm{H}_{2} \mathrm{O}(\cong 300 \mu \mathrm{l})$ \\
Add 1 drop $0.25 \mathrm{~N} \mathrm{H}_{3} \mathrm{PO}_{4}$ \\
Evaporate to dryness \\
\hline
\end{tabular}

For titanite, allanite and rutile the $3 \mathrm{~N} \mathrm{HCl}$ solution goes into the ion-exchange column twice to eliminate the high $\mathrm{Ca}$, Ti and Fe contents, which can inhibit the $\mathrm{Pb}$ readings by the spectrometer. The procedure involves $\mathrm{HBr}$ and is modified after Parrish et al. (1992) and Davis et al. (1997), as summarized in Table II.

The final solution from the columns is deposited on Re filaments (Fig. 2G), for further $\mathrm{Pb}$ and $\mathrm{U}$ readings by the multicollector Finnigan MAT 262 mass spectrometer, which provides the isotopic ratios. The results are treated by the Ludwig (1993) PbDAT and Ludwig (2003) ISOPLOT softwares. The constants used in the age calculations are from Steiger and Jäeger (1977): 
$\lambda \mathrm{U}^{238}=1,55125 \times 10^{-10}$ years $^{-1} ; \lambda \mathrm{U}^{235}=9,8485 \times$ $10^{-10}$ years $^{-1} ; \mathrm{U}^{238} / \mathrm{U}^{235}=137,88$.

TABLE II

Chemical procedure for the extraction of $\mathbf{U}$ and $\mathbf{P b}$ for titanite, rutile and allanite.

\begin{tabular}{|c|}
\hline Column and resin washing \\
\hline Add $150 \mu 1$ of 400 mesh Eichrom $1 \times 8200$ resin \\
\hline Wash with $\cong 300 \mu 1$ MiliQ $\mathrm{H}_{2} 0$ \\
\hline Wash with $\cong 300 \mu 16 \mathrm{~N} \mathrm{HCl}$ \\
\hline Add $120 \mu 13 \mathrm{~N} \mathrm{HCl}$ to condition \\
\hline Add and wash sample \\
\hline Add sample to column \\
\hline Wash with $120 \mu 13 \mathrm{~N} \mathrm{HCl}$ \\
\hline Collect U (I) \\
\hline Replace beakers with U collection 7-ml savillex-A vial \\
\hline Add $240 \mu 10.6 \mathrm{~N} \mathrm{HBr}$ \\
\hline Evaporate to dryness \\
\hline Redissolve in 2 drops $7 \mathrm{~N} \mathrm{HNO}_{3}$ \\
\hline Collect Pb \\
\hline Replace with Pb collection 7-ml savillex-B vial \\
\hline Add $240 \mu 1$ MiliQ $\mathrm{H}_{2} 0$ \\
\hline Replace with waste beakers \\
\hline Wash resin with $240 \mu 1$ MiliQ $\mathrm{H}_{2} 0$ \\
\hline Add 3 drops $7 \mathrm{~N} \mathrm{HNO}_{3}(\cong 90 \mu \mathrm{l})$ \\
\hline Collect U (II) \\
\hline Add sample with U solution (savillex A vial) \\
\hline Wash resin with $300 \mu 17 \mathrm{~N} \mathrm{HNO}_{3}$ \\
\hline Replace with savillex B vial ( $\mathrm{Pb}$ solution) \\
\hline Collect U with $180 \mu 1$ MiliQ $\mathrm{H}_{2} 0$ \\
\hline Add 1 drop $0.25 \mathrm{~N} \mathrm{H}_{3} \mathrm{PO}_{4}$ \\
\hline Evaporate to dryness \\
\hline
\end{tabular}

\section{MASS SPECTROMETRY}

As detailed by Sato and Kawashita (2002), the mass spectrometers are basically constituted by three parts: the ion source; the mass analyzer and the detection system.

\section{Ion source}

The mass spectrometers work with positive or negative ions of elements or molecular species in a ultra-high vacuum system of $10^{-7}$ to $10^{-9}$ mbar. The ionization of the sample is fundamental to promote ion acceleration and deflection, which depend on mass, velocity and electric and magnetic field intensities. Several ionization techniques exist, such as: thermal ionization; plasma; electron impact; and ion impact, being the first the technique currently in routine at $\mathrm{CPGeo}$.

\section{Thermal ionization}

The samples are deposited on a previously cleaned Re filament, which is the preferred one for U-Pb work. There are four types of geometric arrangements for ionization: simple filament, double filament, triple filament and canoe-shaped filament. The ionization efficiency for a certain element varies according to the filament used, work function and the ionization potential of the element. The work function is defined as the energy necessary for an electron to surpass the potential barrier and be freed from the metal in vacuum, whereas the ionization potential is defined as the minimum energy necessary to remove an electron from the atom. The spectrometers that operate with this ionization technique are named "Thermal Ionization Mass Spectrometer" (TIMS). Their efficiency may change depending both on the type of arrangement used and how the sample is loaded on the filament ("sample loading"). For example, $\mathrm{Pb}$ is deposited on the Re filament using a $\mathrm{H}_{3} \mathrm{PO}_{4}$ solution and silicagel, which considerably increases the ionization efficiency.

\section{Mass analyzer}

Ions produced in the thermo-ionic filament are directed to a system of lenses that collimate and accelerate the ions to the mass analyzer. In its simplest version it can be a Quadrupole (QP) or Time of Flight (TOF) analyzer, or versions of higher mass resolution, such as the Electrostatic Analyzer (ESA) and the Magnetic Analyzer (MA). High resolution $(\sim 3000$ a 6000$)$ results when the ions are doubly deflected in ESA and MA, enabling discrimination of some types of isobars.

\section{Detection system}

The TIMS version available at CPGeo has ion detection systems such as Faraday multicollectors and electron multipliers coupled with ions counters or Daly detectors (used in the Micromass spectrometers).

As discussed by Sato and Kawashita (2002) TIMS is a very high precision instrument, but it requires a super-clean chemical laboratory and punctual analyses 
A
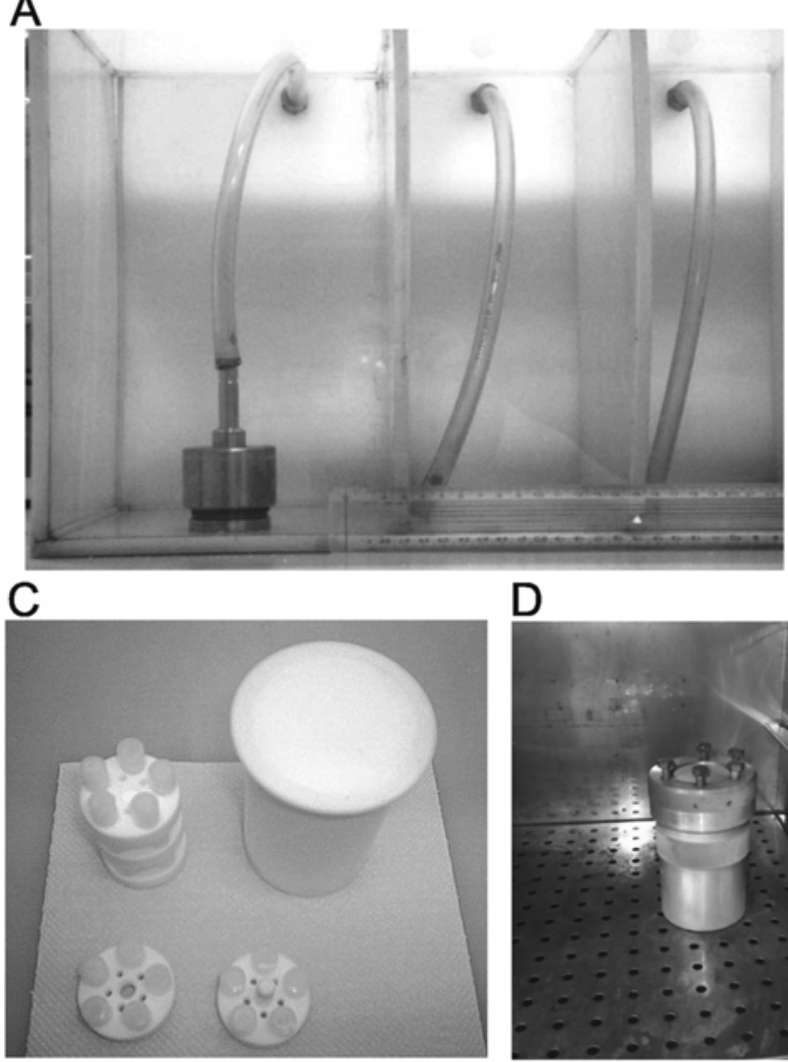

F

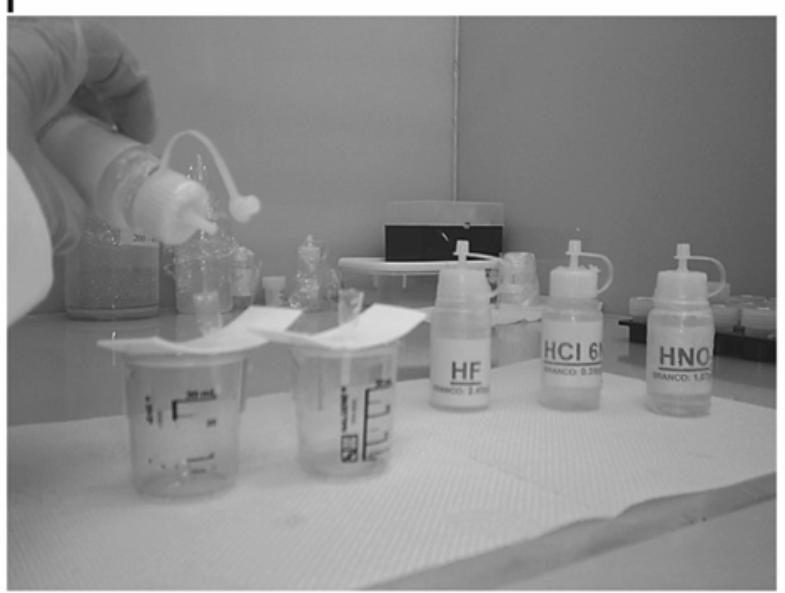

B

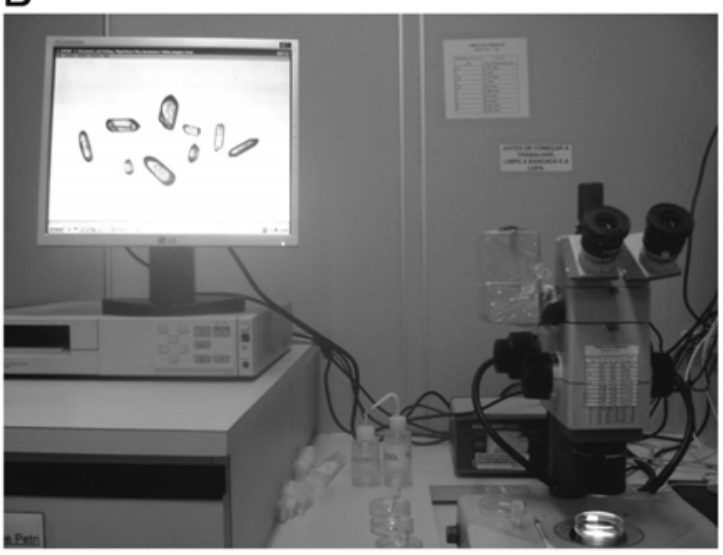

E
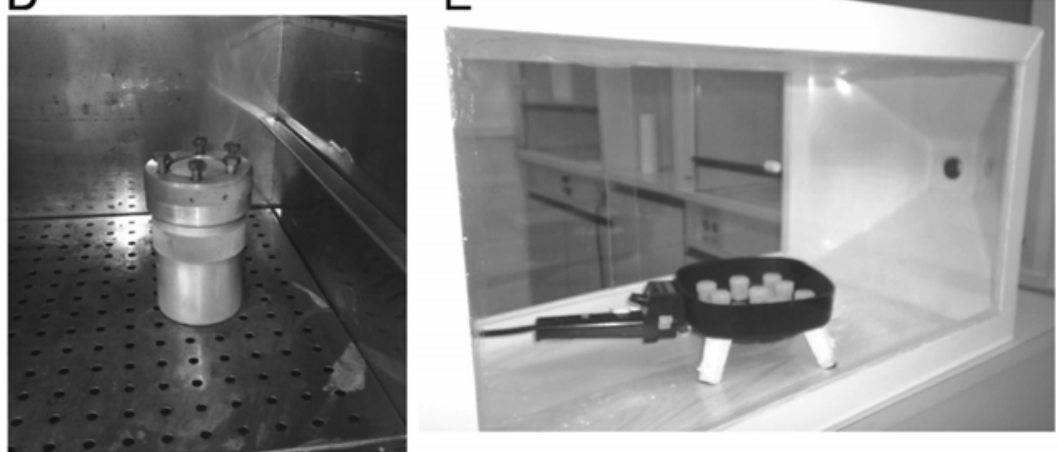

G

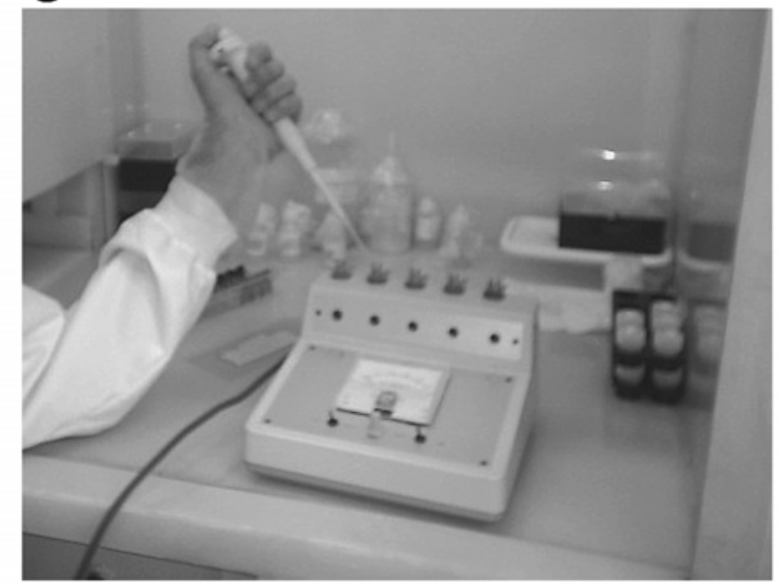

Fig. 2 - Instruments and equipment of the U-Pb Laboratory. The U-Pb Laboratory has microscopes and binoculars for handpicking of minerals, and equipment for photo-documentation of individual mineral grains. For a detailed explanation, see text.

are not possible. On the other hand, by means of TIMS, the "step heating" technique can be applied to single zircon crystals (Kober 1987), provided that the crystal shall have a regular zoning and overgrowth. However, the technique has limited applications and it is time consuming.

\section{TIMS U-Pb DATING RESULTS OF THE U-Pb LABORATORY - CPGeo - USP}

Examples of U-Pb analyses of zircon, baddeleyite, monazite, epidote, titanite and rutile by the isotopic dilution method are presented. All the analysis was carried out at the U-Pb laboratory of CPGeo - USP. 
CASE 1 - ID TIMS versus SHRIMP - THE TRÊS

Córregos Batholith (PARAná State)

Among the different tectonic domains of the Ribeira Belt (RB) of Almeida et al. (1973), the Apiaí Domain constitutes a belt approximately 500-km long and 100$\mathrm{km}$ wide. The Lancinha-Cubatão and Itariri Shear Systems (Fig. 3) mark its limits with the adjacent geologic units.

The Apiaí Domain (AD) is constituted by metavolcanosedimentary rocks of low to medium metamorphic grade. The paleogeographic reference is the Paraná or Paranapanema Craton. The metamorphic rocks of the AD northern portion are represented by the Serra do Itaberaba (Juliani et al. 2000) and São Roque Groups, and those of the southern portion by the Açungui Supergroup metavolcanosedimentary sequences (Campanha and Sadowski 1999).

Among the AD granitic rocks the Cunhaporanga, Batholith Três Córregos and Agudos Grandes batholiths stand out. Important works regarding these granitic rocks are those of Gimenez Filho et al. (2000), Prazeres Filho et al. (2003), Janasi et al. (2001) and Leite et al. (2007).

The Três Córregos Batholith is constituted by a variety of (multi-intrusive) granitic rocks that are distinguished by their petrographic, lithochemical and isotopic characteristics. The analysis of these data suggests a medium- to high-K calc-alkaline lineage of type-I granitoids, formed in a magmatic arc environment.

The São Sebastião Quartz Monzonite Unit (Prazeres Filho 2005) was studied by means of the conventional isotopic dilution method and by SHRIMP-II (RSES - The Australian National University) by Prazeres Filho. The main zircon typology is dominated by long euhedral prismatic crystals (L/W 3:1). Short prisms are rare and more elongated or acicular types are absent (Fig. 4A). Cathodoluminescence images (Fig. 4B) show the development of homogeneous oscillatory zoning, with or without reabsorption textures.

\section{ID-TIMS (U-Pb Lab CPGeo - USP)}

$\mathrm{U}-\mathrm{Pb}$ isotopic data for the quartz monzonitic rocks were obtained by Prazeres Filho (2005), using single zircon populations constituted by prismatic, bipyramidal, transparent crystals of 3:1 L/W ratio (Fig. 4A).

Multi-grain fractions M(-4), M(-5) and NM(-5) of non-abraded crystals were selected. The zircons from fractions $M(-4)$ and $M(-5)$ yielded discordant ages, indicating inheritance and a distinct $\mathrm{Pb}$ loss pattern (Fig. 4B). However, zircons from fraction NM(-5) yielded values concordant with the Concordia Curve and an age of $604 \pm 4 \mathrm{Ma}$, interpreted as the age of crystallization (Fig. 4B).

SHRIMP II (Research School of Earth Sciences - ANU)

Ten zircon crystals from the quartz monzonite of outcrop HP-44 were analyzed. The textural-morphological characteristics of the points analyzed and the graphic data treatment are shown in Figures $4 \mathrm{C}$ and D. The resulting ages concentrate in the Neoproterozoic, between 640 and $600 \mathrm{Ma}$ (Fig. 4D).

Points (spots) both from the nuclei and the rims were chosen for the isotopic analyses, located in domains characterized by oscillatory zoning (Fig. 4C, points 1.1 , $2.1,4.1,5.1$ ) and reabsorption textures (homogeneous portions) with high luminescence (points 3.1). In the oscillatory zoning domain there are no significant differences between ages from the nuclei and from the rims, confirming a single crystallization phase with an average ${ }^{206} \mathrm{~Pb} /{ }^{238} \mathrm{U}$ age of $601 \pm 22 \mathrm{Ma}$ (MSWD 0.018), after the exclusion of discordant points 1.1, 5.1 and 6.1. This result is interpreted as the USS crystallization age. Despite the analytical error, this age is confirmed by the ID-TIMS method.

The ages obtained for the reabsorption domains are older (points 3.1 and 7.1), which suggests that these features are the record of crystallization prior to the zircon neoformation and posterior to a possible nondetected refractory phase. It is not ruled out the possibility that these values are the hybrid ages between overgrowth and nucleus.

It is observed that the final results of both methodologies are similar, where higher precision analyses were obtained by the ID-TIMS. This is due to the quite clear-cut response of this methodology in zircons where the isotopic inheritance and the overgrowth are not significant.

CASE 2 - DAting Metamorphic And Igneous Events IN THE SAME ROCK - THE EMBU DOMAIN

(Southeastern São Paulo State)

In the southeastern portion of São Paulo State, the Embu Domain encompasses mica schist, partially migmatized 


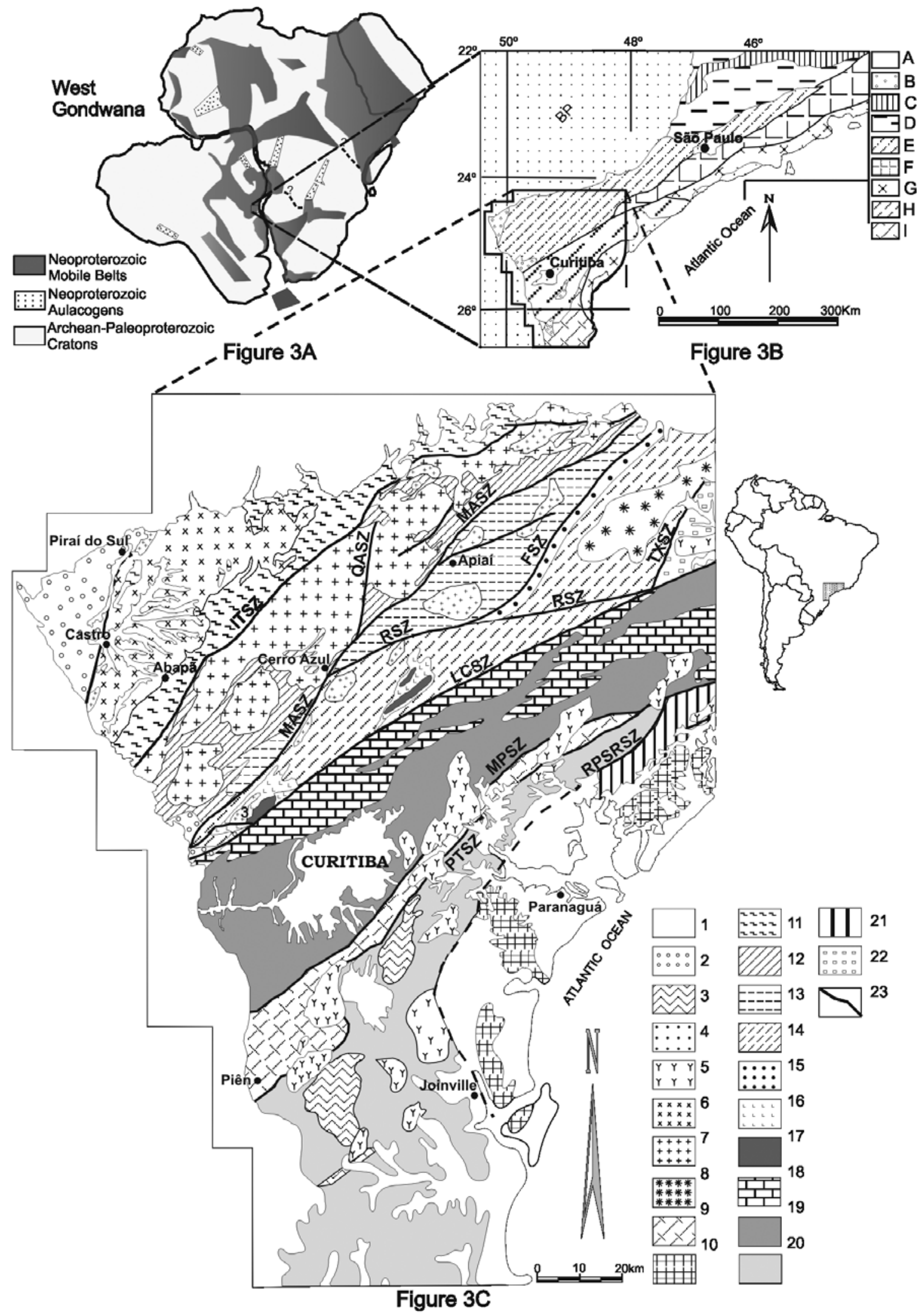


Fig. 3 - Geological and tectonic sketch of the Precambrian areas of southern Brazil. 3A) Paleogeographic reconstruction of West Gondwana (Mod. Unrug 1997). 3B) Geological sketch of central-southern part of the Ribeira Belt (Mod. Campos Neto and Figueiredo 1995, Basei et al. 1997): A) Phanerozoic cover; B) Neoproterozoic/Eopaleozoic basins; C) Alto Rio Grande Belt; D) Socorro-Guaxupé Domain; E) Apiaí Domain; F) Juíz de Fora Domain; G) Serra do Mar Domain; H) Curitiba Domain; I) Luís Alves Domain. 3C) Outline of main geological units of south-southeastern Brazil (Mod. Basei et al. 1997, Harara et al. 1997, Campos Neto 2000). 1) Phanerozoic cover, 2) Eopaleozoic Basins; 3) Neoproterozoic Basins; 4) AD granitic stocks, 5) Serra do Mar Suite alkaline granites. Neoproterozoic Calk-alkaline Granitic Batholiths: 6) Cunhaporanga Batholith; 7) Três Córrego Batholith; 8) Agudos Grandes Batholith; 9) Piên-Mandirituba Batholith; 10) Paranaguá Batholith. Apiaí Domain - Açungui Supergroup: 11) Itaiacoca Group; 12) Água Clara Formation; 13) Lageado Subgroup; 14) Votuverava Formation; 15) Iporanga Formation; 16) Perau Formation; 17) Granite-gneissic nuclei. Curitiba Domai: 18) Capirú Formation; 19) Atuba Complex. Luís Alves Domain: 20) Santa Catarina Granulitic Complex. Serra do Mar Domain: 21) Rio das Cobras Sequence. Juíz de Fora Domain: 22) Embu Complex. 23) Shear Zones (SZ): RPSSZ; Rio Palmital-Serrinha; PTSZ, Piên-Tijucas; MPSZ, Mandirituba-Piraquara; TXSZ, Taxaquara; LCSZ, Lancinha-Cubatão; MASZ, Morro Agudo; RSZ, Ribeira; FSZ, Figueira; QASZ, Quarenta Oitava; ITSZ, Itapirapuã.

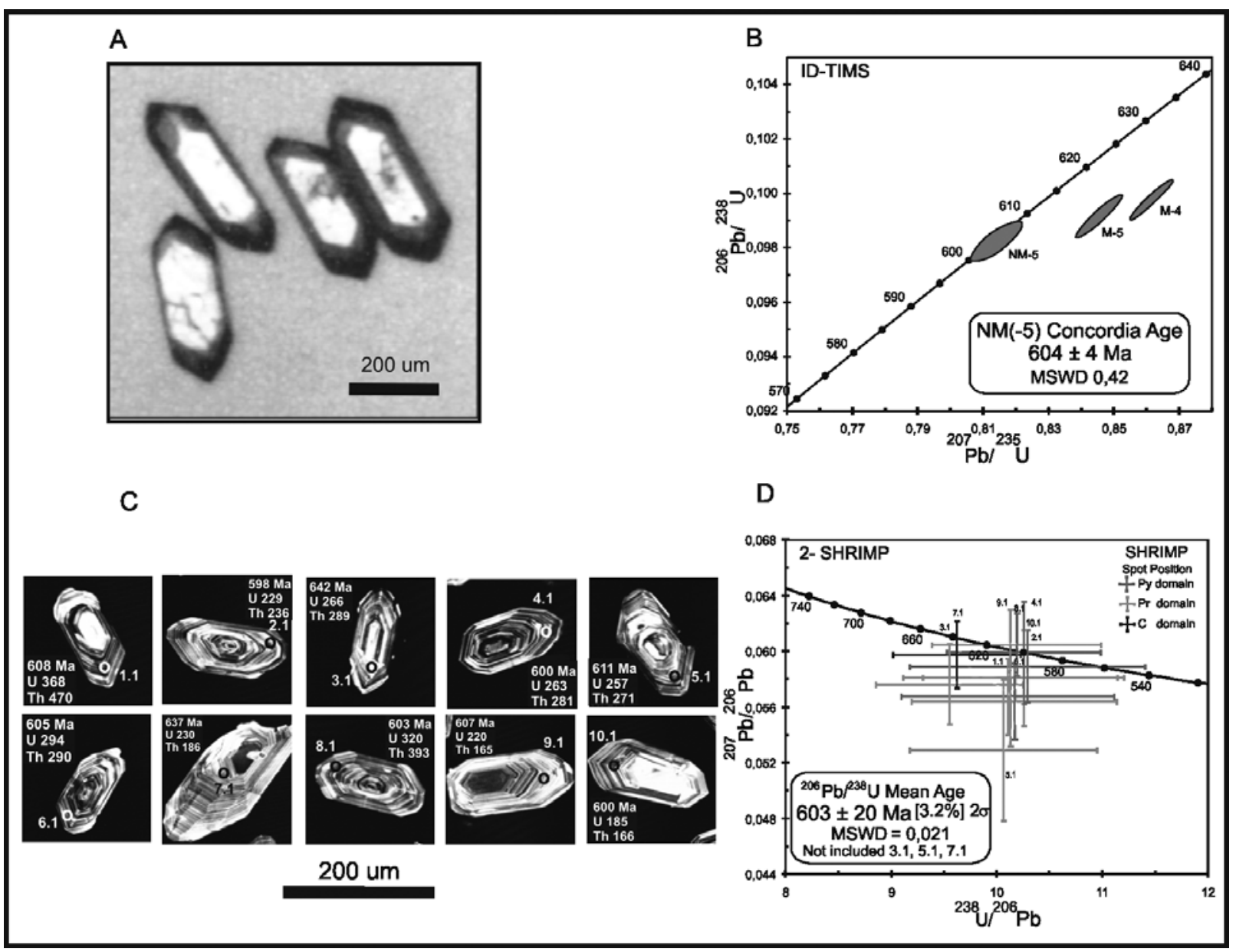

Fig. 4 - Morphological features and TIMS and SHRIMP U-Pb ages of zircon crystals from the São Sebastião Unit - Três Córregos Batholith Quartz monzonite. A) Photomicrograph of selected zircon crystals analyzed by U-Pb ID-TIMS; B) U-Pb Concordia plot of ID-TIMS data. C) Cathodoluminescence (CL) pictures of selected zircon crystals analyzed by SHRIMP II. Ovals (about 20 um in diameter) indicate locations of SHRIMP analyses. U and Th ppm contents. D) Tera-Wasserburg (TW) diagram of SHRIMP for zircons. 
paragneiss and quartzite (Embu Complex), and fine schist, phyllite and subordinately quartzite, metabasite and calc-silicatic rock (Miracatu Sequence). These units are intruded by late-orogenic, high-K and peraluminous calc-alkaline granites (Dantas et al. 1987).

North of the Cubatão Shear Zone (CSZ) in the Juquiá and Sete Barras regions (Fig. 5), metasedimentary rocks of medium to high metamorphic grade are intruded by peraluminous muscovite-biotite monzogranite bodies named Juquiá and Sete Barras Granites (Passarelli et al. 2008).

Mylonitic belts cut the Embu Domain and define important E-W trending and sub-vertical lineaments subparallel to CSZ and the Itariri Shear Zone (ISZ). The Sete Barras and Juquiá granites are oriented and show stretched features, notably the Juquiá Granite. They usually present protomylonitic texture at the rims.

Ages around $790 \mathrm{Ma}$ and $750 \mathrm{Ma}$ were obtained for zircons respectively from the Juquiá and Sete Barras Granites (Figs. 6A and 6B).

$\mathrm{U}-\mathrm{Pb}$ ages around $600 \mathrm{Ma}$ for epidote from the Juquiá Granite (Fig. 6A) and around $620 \mathrm{Ma}$ for monazite from the Sete Barras Granite (Fig. 6B) are interpreted as the time associated with thermal events later to the formation of these granites.

The age around $620 \mathrm{Ma}$ obtained for monazite from the Sete Barras Granite is associated with the syn-collisional phase of the Ribeira Belt (Hackspacher et al. 2000) responsible for an important generation of calc-alkaline magmas. The age obtained for epidote from the Juquiá Granite is possibly associated with the development of the shear zones that limit the granitic bodies. The age around $600 \mathrm{Ma}$ is correlated with the late-collisional phase of the Ribeira Belt, responsible for the lateral escape tectonics with the development of several NE-SW trending shear zones (Hackspacher et al. 2000).

Case 3 - Dating Alkaline Rocks and Baddeleyite - Serra do Mar Alkaline Province

(SÃo SEBASTIÃo ISLAND)

Baddeleyite $\left(\mathrm{ZrO}_{2}\right)$ dating was carried out for alkalifeldspar syenites from the Serraria Massif of the Serra do Mar Alkaline Province (Almeida 1983), São Sebastião Island, northern coast of São Paulo State. Despite the low $\mathrm{Pb}$ concentrations ( $c a .5 \mathrm{ppm}$ ) of the badde- leyite crystals analyzed, a concordant $84 \pm 1$ Ma age was obtained, which coincides with the concordant 85 $\pm 0.3 \mathrm{Ma}$ age yielded by zircon fractions of the same sample (Fig. 7). These ages are interpreted as the time of crystallization of the syenitic rocks.

CASE 4 - DATING Zircon AND TITANITE - Rio PIÊN

Calc-alkaline Granitic Suite (Paraná State)

The Rio Piên calc-alkaline granitic suite (Machiavelli et al. 1993, Harara et al. 1997) is interpreted as a magmatic arc developed between the Luis Alves and Curitiba Microplates (Basei et al. 1997), with granitic rocks yielding ages around $607 \mathrm{Ma}$ (Fig. 8A). The magmatic arc was generated as a consequence of the northward subduction of the oceanic crust that existed between the Luis Alves and Curitiba microplates (Basei et al. 1998). Its deformation is associated with the collision of these Microplates whose estimated youngest age would be around $600 \mathrm{Ma}$, according to K-Ar and U-Pb ages of the isotropic granites that cut the deformed granitoids (Harara et al. 1997).

Zircon fractions from protomylonitic granodiorites showed high $\mathrm{Pb}$ losses (Fig. 8B), and high analytical errors resulted from the analyses. On the other hand a titanite fraction from the same rock yielded a concordant age of $596 \pm 7 \mathrm{Ma}$, which represents the minimum age of crystallization of the rock. However, previous geochronological information obtained from cogenetic granites showed that this age is in fact representative of the time of deformation associated with the collision of the Luis Alves and Curitiba microplates.

CASE 5 - DATING ZIRCON AND TITANITE

- Cordillera Norpatagónica (ARgentina)

In an isotopic study of igneous-metamorphic basement rocks of the Argentinean Andes, zircon U-Pb ages were obtained for the igneous protolith and considered representative of the time of magmatic crystallization and therefore closely related to the emplacement of the igneous bodies dated (Varela et al. 2005).

Zircons from a tonalitic orthogneiss of the San Martín de los Andes Tonalite, southwest of Sañico, Cordillera Norpatagónica, yielded ages of $425 \pm 28 \mathrm{Ma}$. Titanites from metadiorites that occur as small bodies inside the tonalites and represent a minor cogenetic variety yielded a practically concordant age of $360 \mathrm{Ma}$ (Fig. 9). 


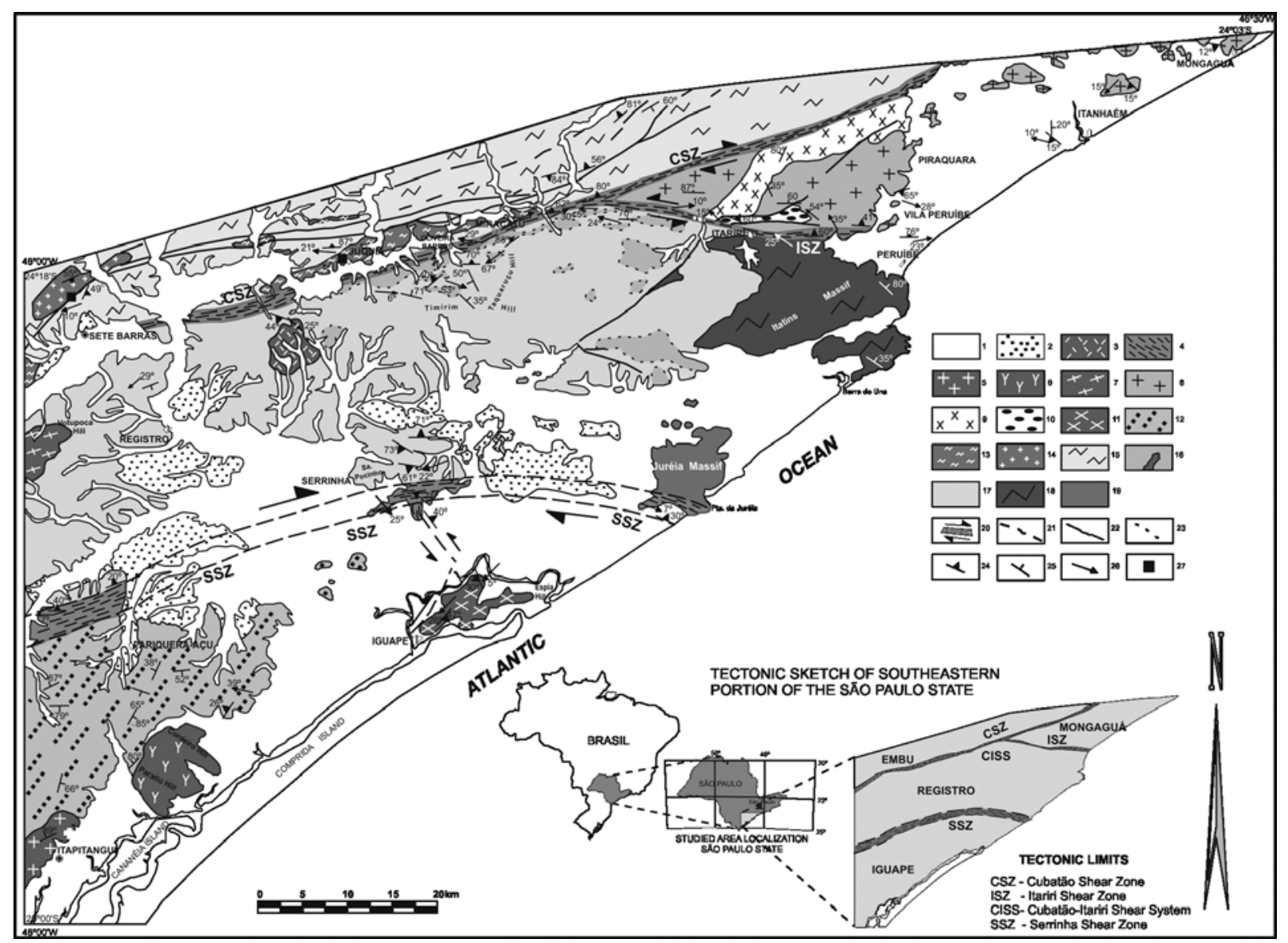

Fig. 5 - Geological Map of southeastern São Paulo State (Passarelli at al. 2008). 1. Quaternary sediments. 2. Tertiary sediments. 3. Juquiá Alkaline Complex (Cretaceous). 4. CISS and SSZ: mylonitic rocks (600-570 Ma). Serra do Mar Granitic Suite (c. 580 Ma): 5. Itapitangui 6. Serra do Cordeiro 7. Serra do Votupoca. Mongaguá Domain: 8. Granite-gneiss-migmatitic Domain (c. 615-580 Ma). 9. Areado Granite (c. 610-580 Ma). 10. Ribeirão do Óleo Granite (c. $580 \mathrm{Ma}$ ). Iguape Domain: 11. Iguape Granite (c. $600 \mathrm{Ma})$. 12. Iguape Metasediments (<2200 Ma). Embu Domain: 13. Juquiá Granite (c. 600 Ma). 14. Sete Barras Granite (c. 630 Ma). 15. Metasediments $(<1600-1800$ Ma). Registro Domain: 16. Granite-gneiss-migmatitic Domain (2100-580 Ma). 17. Gneissic Domain (2200-580 Ma). 18. Itatins Complex (2200$580 \mathrm{Ma}$ ). 19. Cachoeira Sequence (>750 Ma). 20. Main shear zones. 21. Inferred Faults. 22. Lineaments. 23. Gradational geological contact. 24. Mylonitic foliation. 25. Principal foliation. 26. Mineral lineation. 27. The analyzed Sete Barras and Juquiá Granites outcrops.

The zircon age is interpreted as the time of crystallization of the tonalites and the titanite age as that of the metamorphic peak, which are concordant with the biotite K-Ar ages between 370 and $310 \mathrm{Ma}$ (Varela et al. 2005).

\section{CAse 6 - Dating Rutile - Dom Feliciano Belt - Lavalleja Group (Uruguay)}

The approximately NS-trending, 150-km wide Dom Feliciano Belt stretches out for $c a$. $1200 \mathrm{~km}$, thus occupying the whole eastern portion of Southern Brazil and Uruguay (Basei et al. 2000).
From its northernmost limit in Santa Catarina State to its southern end in Uruguay, the Dom Feliciano Belt has an internal organization constituted by three crustal segments characterized from SE to NW by a Granitoid belt (variably deformed calc-alkaline to alkaline granitoid rocks); a Schist belt (volcanosedimentary rocks metamorphosed at greenschist to amphibolite facies), and a Foreland belt (anquimetamorphic sedimentary and volcanic rocks) situated between the schist belt and old terranes to the west.

The Schist belt represents a group of supracrustal rocks distributed between the Granitoid Belt and the 


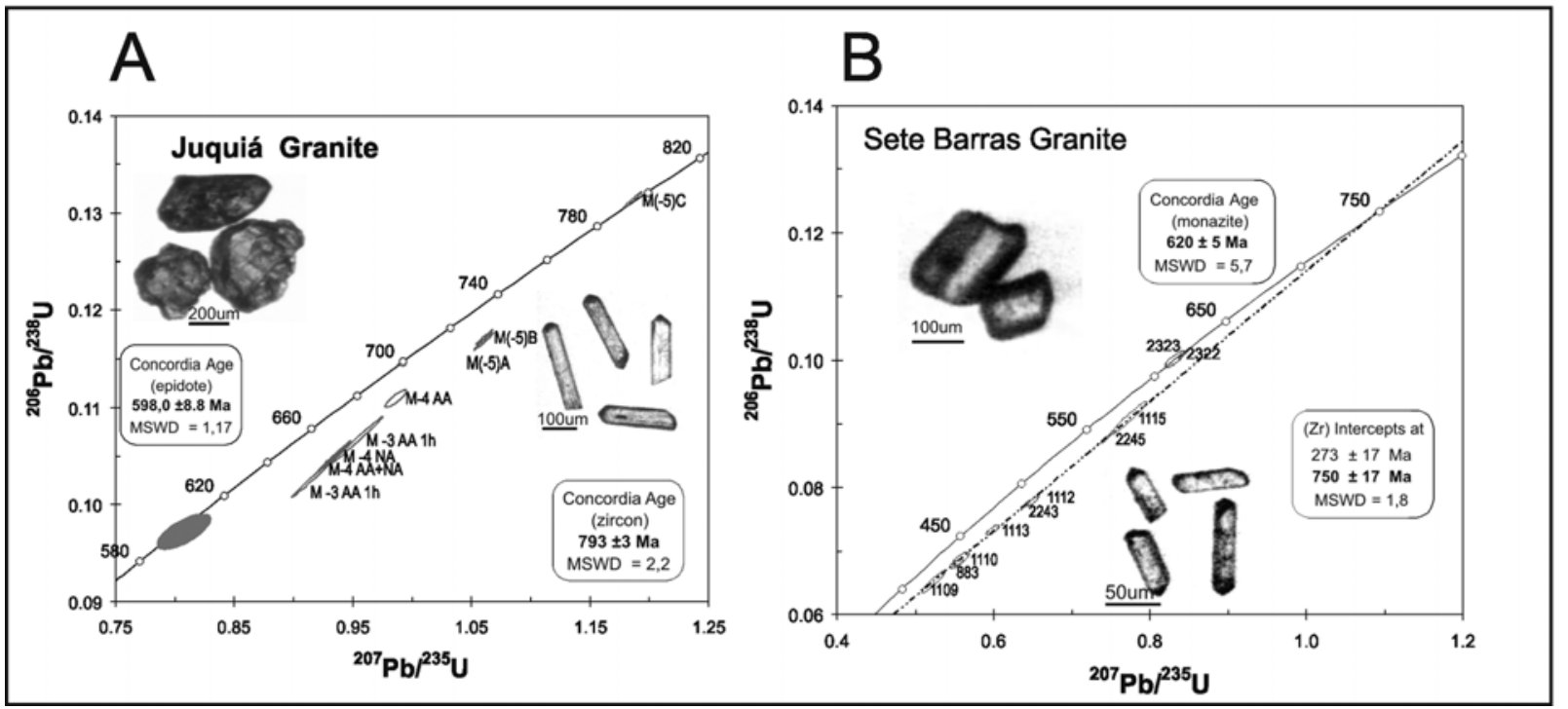

Fig. $6-{ }^{206} \mathrm{~Pb} /{ }^{238} \mathrm{U}$ vs. ${ }^{207} \mathrm{~Pb} /{ }^{235} \mathrm{U}$ Concordia diagram of Embu granites. A) Juquiá granite, zircon and epidote Concordia ages; B) Sete Barras Granite, monazite Concordia age.

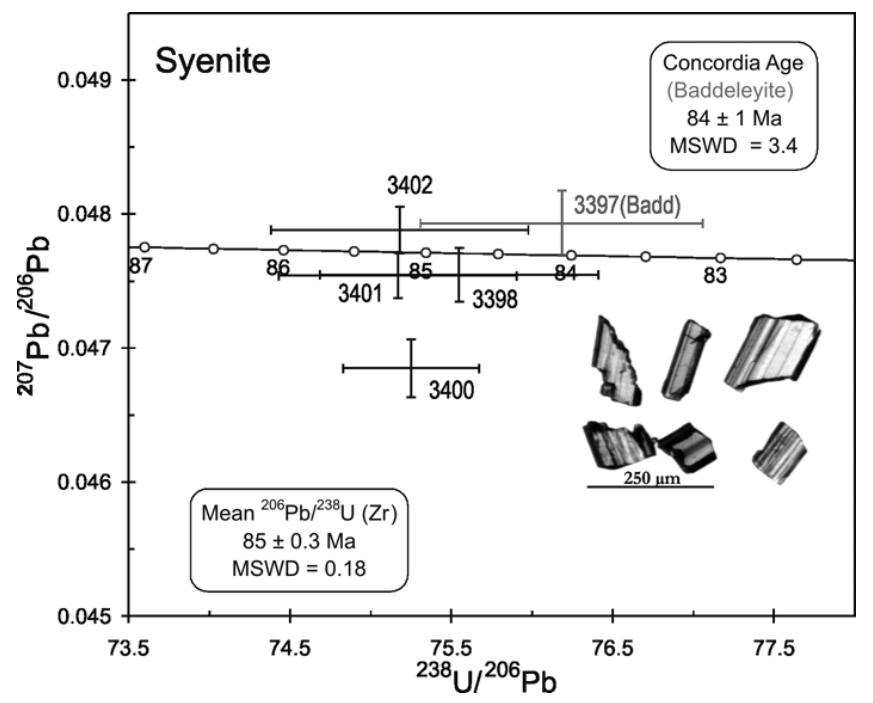

Fig. 7 - Tera-Wasserburg Concordia diagram of zircon and baddeleyite U$\mathrm{Pb}$ isotopic compositions from the Serraria Massif-Serra do Mar Alkaline Province. The inferred magmatic crystallization age for each mineral (average ${ }^{206} \mathrm{~Pb} /{ }^{238} \mathrm{U}$ age corrected for common lead) is indicated.

Foreland Basins. Metasedimentary and metavolcanosedimentary sequences predominate in this segment that discontinuously occurs along a narrow strip of average 40-km width. Three distinct metamorphic complexes can be individualized and are named from north to south, Brusque (SC), Porongos (RS) and Lavalleja (UY).

In Uruguay the Lavalleja Group represents the
Schist Belt southern segment and is composed of three supracrustal units distributed from east to west as follows: Zanja del Tigre, Fuente del Puma and Minas formations (Sánchez Bettucci et al. 2004). The metamorphic grade decreases from $\mathrm{E}$ to $\mathrm{W}$, varying from low amphibolite, followed by greenschist to very low (anquimetamorphic) northwestwards. 


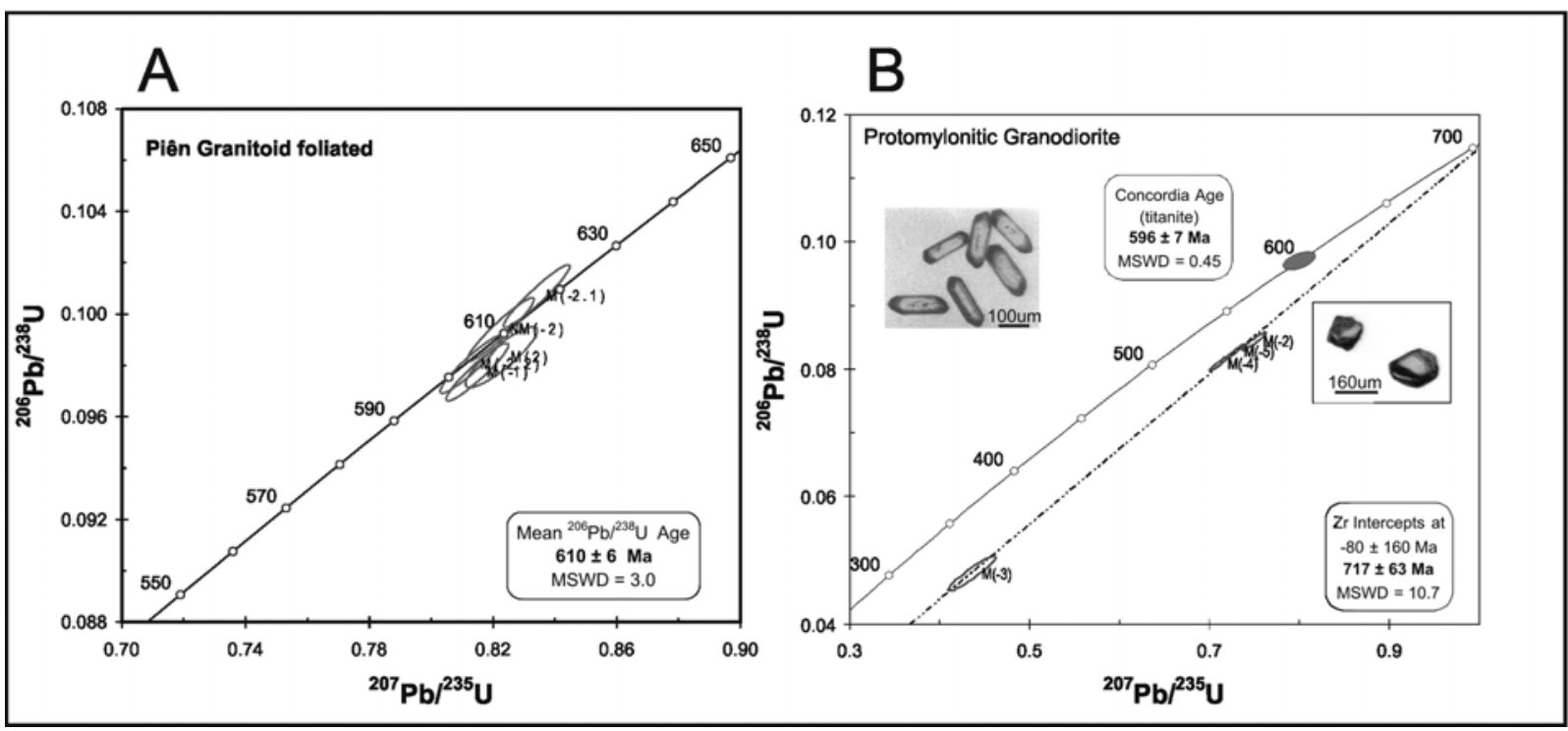

Fig. $8-{ }^{206} \mathrm{~Pb} /{ }^{238} \mathrm{U}$ vs. ${ }^{207} \mathrm{~Pb} /{ }^{235} \mathrm{U}$ Concordia diagram of Piên granitoids. A) Foliated granitoid, zircon Concordia age; B) Protomylonitic granodiorite, titanite Concordia age.

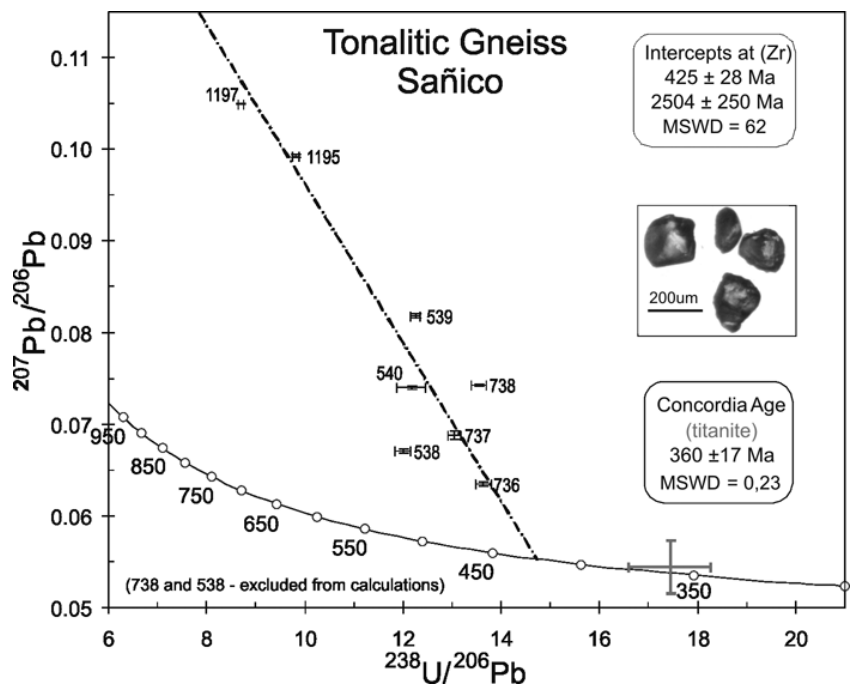

Fig. 9 - Tera-Wasserburg Concordia diagram of zircon and titanite $\mathrm{U}-\mathrm{Pb}$ isotopic compositions from the Tonalitic Gneiss Sañico. The inferred crystallization age for each mineral is indicated.

The Zanja del Tigre Formation corresponds to a metavolcanosedimentary sequence where para- and orthoderived amphibolites and gabbros occur among mica schists, garnet-rich schists and varied marbles. Another metavolcanosedimentary sequence lies on this formation (Fuente del Puma Formation), which is composed of psammo-pelitic rocks (metaconglomerates, calc-arenites, calc-dolomites and mica schists) and, compared to the basal unit, of a more conspicuous volcanic facies (gabbros, basalts, volcanic breccias and rhyolites). The upper Minas Formation is constituted exclusively by sedimentary terms such as metapelites, quartzites, arkoses, and limestones that contain stromatolitic units.

This supracrustal sequence was metamorphosed at low to medium metamorphic grade conditions (Preciozzi et al. 2001). The data available for the metavol- 
canic rocks, between 680 and 690 Ma (K/Ar, Sánchez Bettucci et al. 2004) are scarce.

For a Lavalleja Group metabasalt a concordant zircon age of $667 \pm 4 \mathrm{Ma}$ was obtained and interpreted as the time of formation of the basalts and a concordant rutile age of $624 \pm 14 \mathrm{Ma}$ interpreted as that of the major metamorphic event (Fig. 10).

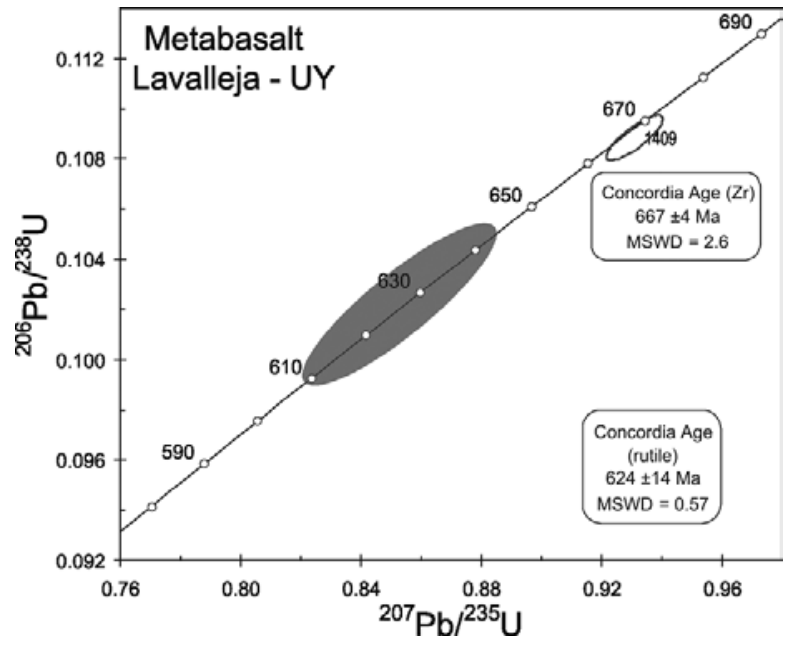

Fig. $10-{ }^{206} \mathrm{~Pb} /{ }^{238} \mathrm{U} v$ s. ${ }^{207} \mathrm{~Pb} /{ }^{235} \mathrm{U}$ Concordia diagram of Fuente del Puma metabasalt. Zircon and rutile Concordia ages are indicated.

\section{DiscusSiON AND FUTURE IMPLEMENTATIONS IN TIMS ANALYSES}

Zircon has a very complex internal structure expressed in different internal domains, with textural, chemical composition and age variations that reflect its geologic history (Vavra 1990, Hanchar and Miller 1993, Hanchar and Hoskin 2003). Thus the study of the zircon internal structure is essential to be carried out for the TIMS methodology. Images of minerals can be obtained by cathodoluminescence (CL), scanning electron microscopy (SEM) or backscattered electrons emission (BSE). Coupled with BSE images, semi-quantitative results can be obtained by EDS to estimate average Th/U ratios of zircon crystals, to identify probable magmatic or metamorphic origin (Vavra et al. 1999), despite the exceptions discussed in Möller et al. (2003).

The zircons CL images (Pidgeon 1992) and transmitted-light microscopy remarks is fundamental. The important internal features of the crystals, such as growth zones, inherited nuclei and growth rims, reabsorption areas, metamictization, fractures, inclusions, etc. are revealed. This information supplies the background to geological evolution of igneous rocks interpretations.

Crystals with inherited nuclei and rims yield $\mathrm{U}-\mathrm{Pb}$ ID-TIMS hybrid ages, because the whole grain is analyzed. However, processes such as mechanical abrasion with pyrite or partial dissolution analysis (PDA, Mattinson 1994) enable the analysis of nuclei and overgrowth rims. The PDA method used in the CPGeo U-Pb laboratory (e.g. Sato et al. 2003) provides good results, despite of $\mathrm{Pb}$ loss, isotopic inheritance or even reverse discordance. The PDA methodology helps to characterize the age of old terranes involved in crustal reworking processes. For these studies, it is very important to be able to analyze very few zircon crystals and guarantee very low laboratory blanks.

Therefore, a crucial aspect of the U-Pb ID-TIMS analysis, especially in zircons, due to its strong isotopic memory, is to avoid crystals that usually present inherited nuclei and metamictization. Figure 11A-1 shows bipyramidal zircons with short-prismatic shape $(1 / \mathrm{w} \sim 1.5)$ whose $C L$ images reveal inherited nuclei, reabsorption areas and melt-precipitated overgrowths (Fig. 11A-2).

Even if extreme care in the hand picking selection of well-formed, clear crystals free of fractures and inclusions, has been taken (Fig. 11B-1), this conventional method cannot completely avoid the presence of unsuitable zircon crystals in the populations (Fig. 11B-2).

The internal features of zircon crystals can also be revealed by lightly HF etching, as described by Pidgeon et al. (1998). The resulting features are similar to those observed in BSE images, but are not always identical to CL images. This method was applied to zircons whose CL images showed very low contrast, making the observation of the crystal internal structure impossible. The susceptibility to HF etching seems to be related to the trace element contents and possibly the metamictization degree.

The advantages of the method are the quickness and low cost. The information obtained is practically the same as that from CL imaging, being only necessary the preparation of epoxy mounts and further HF vapor etching (see Pidgeon et al. 1998 for more details).

New refined techniques will be applied in the near future in the lab, such as CA (Chemical Abrasion) - 


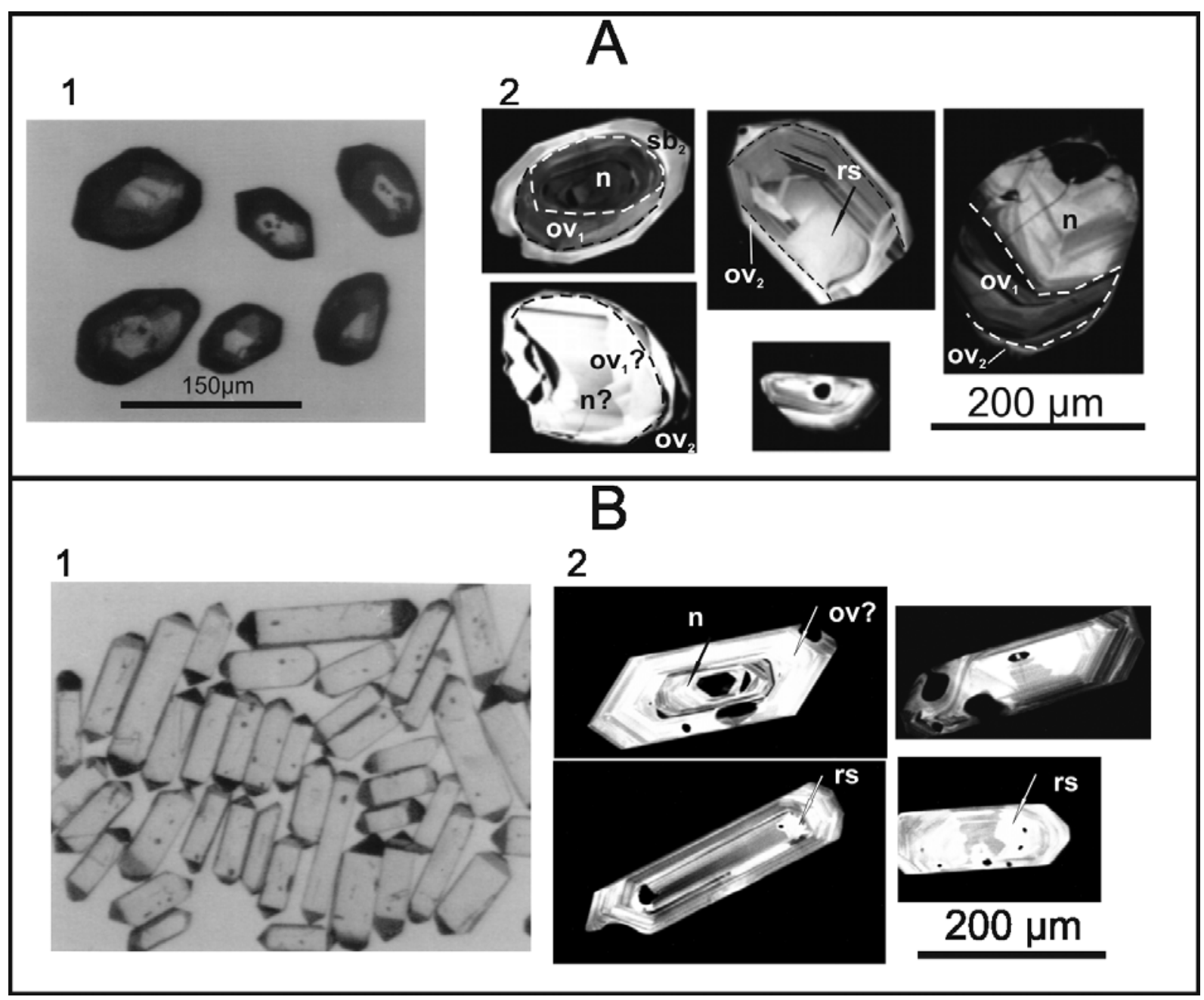

Fig. 11 - Morphological and textural characteristics of zircon crystals. A: 1) Stereoscope photomicrograph of zircon crystals. Monzogranite, Sample HP-21 Piraí do Sul Unit (PSU); 2) Cathodoluminescence images of sections through zircon crystals. rs-reabsorption (indicated by arrows), n-nuclei, ov-overgrowth, stippled line-nuclei/overgrowth limit. B: 1) Stereoscope photomicrograph of zircon crystals; 2) Cathodoluminescence images of sections through zircon crystals. rs - reabsorption (indicated by arrows), $\mathrm{n}$ - nuclei, ov - overgrowth, stippled line-nuclei/overgrowth limit.

TIMS (Mattinson 2005). This method enables the complete removal of parts of the crystal that underwent $\mathrm{Pb}$ loss so that the analysis of a residual, isotopically closed system is made possible. The CA-TIMS system includes a high-temperature treatment to anneal the damage caused by radiation to the crystalline lattice and spontaneous fission processes, thus eliminating the elemental and isotopic leaching effects that limited the use of certain methods, such as step-wise dissolution or partial dissolution analysis (PDA). Then, the annealed zircons are submitted to a series of partial dissolution steps at progressively higher temperatures.
Additionally the implementation of the routine for other accessory minerals such as epidote and the improvement of the routines for minerals such as titanite, rutile and apatite will considerably contribute to the study of polycyclic terranes.

\section{FINAL CONSIDERATIONS}

The U-Pb geochronology is one of the most precise methods used to temporally establish igneous and metamorphic processes. The use of high-Tc minerals such as zircon enables the dating of crystallization under igneous conditions and of metamorphic events. Moreover, 
the use of lower-Tc minerals allows the characterization of the thermal history of igneous and metamorphic terranes.

The improvements on the isotope dilution - thermal ionization mass-spectrometry (ID-TIMS) technique are remarkable, as well as those concerning sample preparation, mineral selection, laboratory blanks, and acquisition of very precise ages, allowing the characterization of superposed geologic events at unprecedented levels.

Due to the 'open-system' behavior of the U-Pb systematics, exemplified by isotopic disequilibrium, $\mathrm{Pb}$ loss and inheritance (detailed revision in Hanchar and Hoskin 2003), there is increasing need for advanced studies and the innovation of new techniques for a permanent improvement of the methodology.

In summary it can be established that the TIMS systematics should be used when high-precision analyses are required, for example, when several successive magmatic and/or metamorphic events must be individualized in a short time interval. The high reliability and precision conditions also involve the use of imaging techniques in order to obtain details of the mineral internal features (detailed revision in Parrish and Noble 2003).

In turn, the SIMS systematics is applicable to the study of polycyclic terranes, where high spatial resolution analyses are needed, in zircon crystals with isotopic inheritance, and in metamorphic rocks that are usually affected by partial opening of the isotopic U-Th-Pb system, with consequence overgrowth and even reabsorption areas.

The choice of the technique to be applied will depend initially on the objective of the research and the geological context. The combined use of the TIMS and SIMS techniques is already a reality, summing the advantages of each of them. These techniques are totally complementary and by no means exclusive and will provide the precise characterization of tectono-thermal events that affected terranes of complex geologic-geochronological evolution.

\section{ACKNOWLEDGMENTS}

Financial contributions of Fundação de Amparo à Pesquisa do Estado de São Paulo (FAPESP) are acknowledged. Hélcio José dos Prazeres Filho is thanked for stimulating discussions and help with the examples of SHRIMP II analyses and CL imaging. We thank Fernando Preciozzi, Silvio Vlach and Enos Sato for permission to publicize $\mathrm{U}-\mathrm{Pb}$ data from their own researches.

\section{RESUMO}

O Centro de Pesquisas Geocronológicas (CPGeo), um dos centros interdepartamentais do Instituto de Geociências (IG) da Universidade de São Paulo (USP), desde 1964 desenvolve estudos relacionados a diversos processos geológicos que se associam a diferentes tipos de rochas. A técnica amplamente utilizada no Laboratório U-Pb é a diluição isotópica por espectrometria de massa termo ionizada (ID-TIMS). Esta sistemática proporciona resultados bastante confiáveis e precisos na determinação das idades de eventos geológicos superpostos. Entretanto, o comportamento de sistema aberto como perda de $\mathrm{Pb}$, problemas de herança isotópica e processos de metamictização, nos permite o entendimento do poder e limitação da geocronologia e termocronologia U-Pb. Neste artigo apresentamos a metodologia atualmente utilizada no Laboratório $\mathrm{U}-\mathrm{Pb}$ do $\mathrm{CPGeo-IGc-USP,}$ as melhorias atingidas na técnica ID-TIMS e alguns dados obtidos em zircão, epídoto, titanita, baddeleyita e rutilo de diferentes tipos de rochas de alguns domínios da região sul-sudeste brasileira e da Argentina e Uruguai.

Palavras-chave: metodologia U-Pb (diluição isotópica TIMS), geocronologia U-Pb em minerais acessórios, laboratório U-Pb - CPGeo-IGc-USP.

\section{REFERENCES}

Ahrens LH. 1955. The convergent lead ages of the olds monazites and uranites. Geochim Cosmochim Acta 1: 294.

ALMEIDA FFM. 1983. Relações tectônicas das rochas alcalinas mesozóicas da região meridional da Plataforma Sul-Americana. Rev Bras Geocienc 13: 139-158.

Almeida FFM, Amaral G, Cordani UG AND KaWASHITA K. 1973. The Precambrian Evolution of the South American Cratonic Margin south of Amazon River. In: NAIRN AEM AND STEHLI FG (Eds), The Ocean Basins and Margins. New York, Plenun 1(11): 411-446.

BARth S, OBerli F And MeIER M. 1994. Th-Pb versus U$\mathrm{Pb}$ isotope systematics in allanite from co-genetic rhyolite and granodiorite: implications for geochronology. Earth Plan Sci Lett 124: 149-159. 
Basei MAS, Siga Jr O, SATo K And Spröesser WM. 1995. A metodologia Urânio-Chumbo na Universidade de São Paulo: Princípios, aplicações e resultados obtidos. An Acad Bras Cienc 67: 221-237.

Basei MAS, Siga Jr O, Reis Neto JM, Harara OMM, Passarelli CR and Machiavelli A. 1997. Geochronological map of the Precambrian terrains of Paraná and Santa Catarina States, southern Brazil: Tectonic Implications. In: SoUth AMER SyMP Isot GeOL, I, Extended Abstracts, Campos do Jordão, p. 44-46.

BASei MAS, McReath I AND Siga JR O. 1998. The Santa Catarina Granulite Complex of Southern Brazil, A Review. Gondwana Res 1: 383-391.

Basei MAS, Siga Jr O, Masquelin H, Harara OMM, Reis Neto JM And Preciozzi F. 2000. The Dom Feliciano Belt of Brazil and Uruguay and its Foreland Domain, the Rio de la Plata Craton, framework, tectonic evolution and correlation with similar provinces of Southwestern Africa. In: CoRdANI UG ET AL. (Eds), Tectonic Evolution of South American Platform, p. 311-334.

BERTRAND JM, RODDICK JC, VAN KRANENDONK MJ AND ERMANOVICS I. 1993. U-Pb geochronology of deformation and metamorphism across a central transect of the Early Proterozoic Torngat Orogen, North River map area, Labrador. Can J Earth Sci 30: 1470-1489.

Campanha GAC and Sadowski GR. 1999. Tectonics of the southern portion of the Ribeira Belt (Apiaí) Domain. Precamb Res 98: 31-51.

Campos Neto MC. 2000. Orogenic Systems from Southwestern Gondwana: an approach to Brasiliano-Pan African cycle and orogenic collage in southeastern Brazil. In: CORDANI UG ET AL. (Eds), Tectonic Evolution of South American Platform, p. 335-365.

Campos Neto MC and Figueiredo MCH. 1995. The Rio Doce Orogeny, southeastern Brazil. J South Am Earth Sci 8: $143-162$.

CATlos EJ, Sorensen SS AND HARrison TM. 2000. Th$\mathrm{Pb}$ ion-microprobe dating of allanite. Amer Mineral 85: 633-648.

CHERNIAK DJ. 1993. Lead diffusion in titanite and preliminary results on the effects of radiation damage on $\mathrm{Pb}$ transport. Chem Geol 110: 177-194.

Cherniak DJ. 2000. Pb diffusion in rutile. Contrib Mineral Petrol 139: 198-207.

Cherniak DJ And Watson EB. 2000. Pb diffusion in zircon. Chem Geol 172: 5-24.

Cherniak DJ AND Watson EB. 2003. Diffusion in zircon.
In: HANCHAR JM AND HOSKIN PWO (Eds), Zircon. Rev Mineral Geochem 53: 113-143.

ChERNIAK DJ, WATSON EB, HARRISON TM AND GRove M. 2004. Pb diffusion in monazite: A combined RBS/ SIMS study. Geochim Cosmochim Acta 68: 829-840.

COPELAND P, PARRISH RR AND HARRISON TM. 1988. Identification of inherited radiogenic $\mathrm{Pb}$ in monazite and its implications for U-Pb systematics. Nature 333: 760763.

CORFU F. 1988. Differential response of U-Pb systems in coexisting accessory minerals, Winnipeg River Subprovince, Canadian Shield: implications for Archean crustal growth and stabilization. Contrib Mineral Petrol 98: 312-325.

CORFu F AND ANDREWs AJ. 1986. A U-Pb age for mineralized Nipissing diabase, Gowganda, Ontario. Can J Earth Sci 23: 107-109.

CORFU F AND EASTON RM. 1997. Sharbot Lake terrane and its relationships to Frontenac terrane, Central Metassedimentary Belt, Grenville Province: new insights from $\mathrm{U}-\mathrm{Pb}$ geochronology. Can J Earth Sci 34: 1239-1257.

CORFU F AND EASTON RM. 2000. U-Pb evidence for polymetamorphic history of Huronian rocks within the Grenville front tectonic zone east of Sudbury, Ontario, Canada. Chem Geol 172: 149-171.

DAHL PS. 1997. A crystal-chemical basis for $\mathrm{Pb}$ retention and fission-track annealing systematics in U-bearing minerals, with implications for geochronology. Earth Planet Sci Lett 150: 277-290.

Dantas ASL, Gimenez Filho A, TeiXeira AL, NAGATA N, Fernandes LA, Albuquerque Filho JL AND FRASCÁ MHBO. 1987. Evolução geológica e estrutural da faixa costeira nas regiões de Juquiá e Miracatu, Sul do Estado de São Paulo. In: Simp Reg GeOL, 6 Rio Claro. Atas... SBG/NSP 2: 173-189.

DAVIS WJ. 1997. U-Pb zircon and rutile ages from granulite xenoliths in the Slave province: evidence for mafic magmatism in the lower crust coincident with Proterozoic dike swarms. Geology 25: 343-346.

DaVis DW, Schandl ES AND Wasteneys HA. 1994. $\mathrm{U}-\mathrm{Pb}$ dating of minerals in alteration halos of Superior Province massive sulfide deposits: syngenesis versus metamorphism. Contrib Mineral Petrol 115: 427-437.

Davis WJ, McNicoll VJ, Bellerive DR, SAntowski K AND SCOTT DJ. 1997. Modified chemical procedures for the extraction and purification of uranium from titanite, allanite, and rutile in the Geochronology Laboratory, Geological Survey of Canada. Radiogenic Age and Isotopic Studies: Report 10, Geol Surv Can, Cur Res, p. 3335. 
DICKIN AP. 1995. Radiogenic Isotope Geology. Cambridge University Press, $490 \mathrm{p}$.

FAure G ANd Mensing TA. 2005. Isotopes: Principles and Applications, $3^{\text {rd }}$ ed., New Jersey: J Wiley \& Sons, 897 p.

Foster G, Gibson HD, Parrish R, Horstwood M, FRASER J AND TINDLE A. 2000. Textural, chemical and isotopic insights into the nature and behaviour of metamorphic monazite. Chem Geol 191: 183-207.

Frost BR, ChAmberlain KR AND SCHUmaCHeR JC. 2000. Sphene (titanite): phase relations and role as a geochronometer. Chem Geol 172: 131-148.

Gimenez Filho aG, Janasi VA, CAmpanha GAC, TeiXeira W AND TREVIzoli JR LE. 2000. U-Pb dating and $\mathrm{Rb}$-Sr isotope geochemistry of the Eastern portion of the Três Córregos Batolith Ribeira Fold Belt, São Paulo, Brazil. Rev Bras Geocienc 30: 45-50.

Hackspacher PC, Dantas EL, Spoladore A, Fetter AH AND OlIVEIRA MAF DE. 2000. Evidence of Neoproterozoic Backarc Basin development in the Central Ribeira Belt, Southeastern Brazil: new geochronological and geochemical constraints from the São Roque - Açungui Groups. Rev Bras Geocienc 30: 110-114.

HANCHAR JM AND Hoskin PWO. 2003. Zircon. Reviews in Mineralogy and geochemistry Vol. 53. Mineralogical Society of America, Washington, DC, $500 \mathrm{p}$.

Hanchar JM AND Miller CF. 1993. Zircon zonation patterns as revealed by cathodoluminescense and backscattered electron images: implications for interpretation of complex crustal histories. Chem Geol 110: 1-13.

HARARA OMM, BASEI MAS AND Siga JR O. 1997. Geochronological and geochemical data on the transition zone between Luis Alves and Atuba complexes, south Brazil. In: South Amer Symp Isot Geol, I, Extended Abstracts, Campos do Jordão, p. 134-136.

Hawkins DP, Bowring SA, Ilg BR, Karlstrom KE AND WILliams ML. 1996. U-Pb geochronologic constraints on the Paleoproterozoic crustal evolution of the Upper Granite Gorge, Grand Canyon, Arizona. Geol Soc Am Bull 108: 1167-1181.

Heaman LM and LeCheminant AN. 1993. Paragenesis and $\mathrm{U}-\mathrm{Pb}$ systematics of baddeleyite $\left(\mathrm{ZrO}_{2}\right)$. Chem Geol 110: 95-126.

Heaman LM And LeCheminant AN. 2000. Anomalous $\mathrm{U}-\mathrm{Pb}$ systematics in mantle-derived baddeleyite xenocrysts from Île Bizard: evidence for high temperature radon diffusion? Chem Geol 172: 77-93.

HEAMAN LM AND PARRISH R. 1991. U-Pb geochronology of accessory minerals. In: HEAMAN L AND LUDDEN JN (Eds), Applications of Radiogenic Isotope Systems to Problems in Geology. Min Assoc Can, Short Course Handbook, Ottawa, p. 59-102.

JANASI VA, LEITE RJ AND VAN SCHMUS WR. 2001. U-Pb chronostratigraphy of the granitic magmatism in the Agudos Grandes Batholith (west of São Paulo) - implications for the evolution of the Ribeira Belt. J South Am Earth Sci 14: 363-376.

JULIANI C, HACKSPACHER PC, DANTAS EL AND FETTER AH. 2000. The Mesoproterozoic volcano-sedimentary Serra do Itaberaba Group of central Ribeira Belt: implications for the age of overlying São Roque Group. Rev Bras Geocienc 30: 82-86.

Kim H, CheOng C AND CHO M. 2007. The effect of allanite inclusions on $\mathrm{U}-\mathrm{Pb}$ step-leaching ages and $\mathrm{Sm}-\mathrm{Nd}$ isotope systematics of garnet from the Ogcheon metamorphic belt, South Korea. Chem Geol 236: 27-41.

KoBer B. 1987. Single-grain evaporation combined with $\mathrm{Pb}^{+}$emitter bedding for ${ }^{207} \mathrm{~Pb} /{ }^{206} \mathrm{~Pb}$ investigations using thermal ion mass spectrometry, and implications for zirconology. Contrib Mineral Petrol 96: 63-71.

Kosler J And Sylvester PJ. 2003. Present trends and the future of zircon in geochronology: laser ablation ICPMS. In: HANCHAR JM AND HOSKIN PWO (Eds), Zircon. Rev Mineral Geochem 53: 243-275.

KROGH TE. 1982a. Improved accuracy of U-Pb zircon dating by selection of more concordant fractions using a high gradient magnetic separation technique. Geoch Cosm Acta 46: 631-635.

KROGH TE. 1982b. Improved accuracy of U-Pb zircon ages by the creation of more concordant systems using an air abrasion technique. Geoch Cosm Acta 46: 637-649.

KRYMSKY RS, MACAMBIRA MJB, LAFON JM AND Estumano GS. 2007. Uranium-lead dating method at the Pará-Iso isotope geology laboratory, UFPA, Belém Brazil. An Acad Bras Cienc 79: 115-128.

LEE JKW, Williams I AND Ellis DJ. 1997. Pb, U and Th diffusion in natural zircon. Nature 390: 159-163.

Leite RJ, JANAsi VA, CReaser RA ANd HeAman LM. 2007. The late- to post-orogenic transition in the Apiaí Domain, SE Brazil: constraints from the petrogenesis of the Neoproterozoic Agudos Grandes Granite Batholith. J South Am Earth Sci 23: 213-235.

LUDWIG KR. 1977. Effect of initial radioactive daughter disequilibrium on $\mathrm{U}-\mathrm{Pb}$ isotope apparent ages of young minerals. J Res US Geol Surv 5: 663-667. 
LUDWIG KR. 1993. PBDAT, a computer program for processing $\mathrm{Pb}-\mathrm{U}-\mathrm{Th}$ isotope data. USGS Open File Report, $88,34 \mathrm{p}$.

LUDWIG KR. 2003. User's manual for Isoplot 3.0: a geochronological toolkit for Microsoft Excel. Berkeley Geochronology Center, Special Publication n. 4, 71 p.

Machiavelli A, BASei MAS And Siga JR O. 1993. Suíte Granítica Rio Pien: um arco magmático do Proterozóico Superior na Microplaca Curitiba. Geochim Bras 7: 113129.

Mattinson JM. 1994. A study of complex discordance in zircons using step-wise dissolution techniques. Contrib Mineral Petrol 116: 117-129.

MATTINSON JM. 2005. Zircon U-Pb chemical abrasion ("CA-TIMS") method: Combined annealing and multistep partial dissolution analysis for improved precision and accuracy of zircon ages. Chem Geol 220: 47-66.

MezGer K AND Krogstad J. 1997. Interpretation of discordant $\mathrm{U}-\mathrm{Pb}$ in zircon ages: an evaluation. J Metamorph Geol 15: 127-140.

Mezger K, Hanson GN And Bohlen SR. 1989. High precision $\mathrm{U}-\mathrm{Pb}$ ages of metamorphic rutile: applications to the cooling history of high-grade terranes. Earth Planet Sci Lett 96: 106-118.

Mezger K, Rawnsley C, Bohlen S and Hanson G. 1991. U-Pb garnet, sphene, monazite, and rutile ages: implications for the duration of high-grade metamorphism and cooling histories Adirondack Mountains, New York. J Geol 99: 415-428.

Mezger K, Essene EJ, van der Pluijm BA and HalliDAY AN. 1993. U-Pb gecochonology of Grenville orogen of Ontario and New York: constraints on ancient tectonics. Contrib Mineral Petrol 114: 13-26.

Miller BV, Dunning GR, Barr SM, Raeside RP, JAMIESON RA AND REYNOLDS PH. 1996. Magmatism and metamorphism in a Grenvillian fragment: $\mathrm{U}-\mathrm{Pb}$ and ${ }^{40} \mathrm{Ar} /{ }^{39} \mathrm{Ar}$ ages from the Blair River Complex, Northern Cape Breton Island, Nova Scotia, Canada. Geol Soc Am Bull 108: 127-140.

Möller A, O’Brien PJ, Kennedy A And Kröner A. 2003. The use and abuse of Th-U ratios in the interpretation of zircon. Geophys Res Abstr 5, p. 12113.

Muir RJ, Ireland TR, WEAVER SD AND BRADShaW JD. 1994. Ion microprobe U-Pb zircon geochronology of granitic magmatism in the Western Province of the South Island, New Zealand. Chem Geol (Isot Geosc Sect) 113: 171-189.
PARRISH RR. 1990. U-Pb dating of monazite and its application to geological problems. Can J Earth Sci 27: 1431-1450.

PARrish RR And Noble SR. 2003. Zircon U-Th-Pb Geochronology by Isotope Dilution - Thermal Ionization Mass Spectrometry (ID-TIMS). In: HANCHAR JM AND Hoskin PWO (Eds), Zircon. Rev Miner Geochem 53: 183-213.

PARRISH RR, RODDIK JC, LOVERIDGE WD AND SULLIAN RW. 1987. Uranium-lead analytical techniques at the geochronology laboratory, Geological Survey of Canada. In: RAdiogenic Age And Isotopic Studies: Report 1, Geol Surv Can 87(2): 3-7.

PARRish RR, Bellerive D AND Sullivan RW. 1992. $\mathrm{U}-\mathrm{Pb}$ chemical procedures for titanite and allanite in the Geochronology Laboratory, Geological Survey of Canada. Radiogenic Age and Isotopic Studies: Report 5, Geol Surv Can 91(2): 187-190.

Passarelli CR, Wemmer K, Basei MAS And Siga JR O. 2008. Tectono-thermal evolution of the SE São Paulo State Precambrian terranes. In: SOUTH AMER SyMP Isot GeOL, VI, Proceedings in CD-ROM, Paper 16. ISSN 1851-6963, San Carlos de Bariloche, 5 p.

PIDGEON RT. 1992. Recrystallization of oscillatory zoned zircon: some geochronological and petrological implications. Contrib Mineral Petrol 110: 463-472.

Pidgeon RT, Bosch D AND BRuguier O. 1996. Inherited zircon and titanite U-Pb system in an Archean syenite from Southwestern Austrália: implications for U-Pb stability of titanite. Earth Planet Sci Lett 141: 187-198.

Pidgeon RT, Nemchin AA And Hitchen GJ. 1998. Internal structures of zircons from Archaean granites from the Darling Range batholith: implications for zircon stability and interpretation of zircon $\mathrm{U}-\mathrm{Pb}$ ages. Contrib Mineral Petrol 132: 288-300.

POITRASSON F. 2002. In situ investigations of allanite hydrothermal alteration: examples from calc-alkaline and anorogenic granites of Corsica (southeast France) Contrib Mineral Petrol 142: 485-500.

PraAmsma T, Wodicka N And EAston RM. 2000. Evidence for magmatism of Elzevirian age in the Sharbot Lake domain, Central Metasedimentary belt, Grenville Province, Ontario. Geol Surv Can, Radiogenic age and isotopic studies: Report 13: 1-8.

PraZeres Filho HJ. 2005. Caracterização geológica e petrogenética do Batólito granítico Três Córregos (PR$\mathrm{SP})$ : geoquímica isotópica (Nd-Sr-Pb), idades (ID-TIMS/ 
SHRIMP) e $\delta^{18} \mathrm{O}$ em zircão. $\mathrm{PhD}$ Thesis. São Paulo, IGc-USP, $207 \mathrm{p}$.

Prazeres Filho HJ, Basei mas, harara OMM, PAssarelli CR AND Siga JR O. 2003. Litogeoquímica e geologia isotópica (U-Pb, Sr-Nd-Pb) do magmatismo granítico dos Batólitos Cunhaporanga e Três Córregos, na porção sul do Cinturão Ribeira. Bol IGc-USP, Sér Cient 3: $51-70$.

Preciozzi F, Peel E, Muzio R, Ledesma JJ And Guerequiz R. 2001. Dom Feliciano Belt and Punta del Este Terrane: Geochronological features. In: SouTH AM Symp Isot GeOL, III, Extended Abstracts, Pucón, Chile, p. 217-220.

RODDICK JC AND BEVIER ML. 1995. U-Pb dating of granites with inherited zircon: Conventional and ion microprobe results from two Paleozoic plutons, Canadian Appalachians. Chem Geol 119: 307-329.

Romer RL AND SIEGESMUND S. 2003. Why allanite may swindle about its true age. Contrib Mineral Petrol 146: 297-307.

Romer RL AND Xiao Y. 2005. Initial Pb-Sr(-Nd) isotopic heterogeneity in a single allanite-epidote crystal: implications of reaction history for the dating of minerals with low parent-to-daughter ratios. Contrib Mineral Petrol 148: $662-674$.

Rubatto D, Williams IS AND BUiCK IS. 2001. Zircon and monazite response to prograde metamorphism in the Reynolds Range, central Australia. Contrib Minral Petrol 140: 458-468.

Sánchez Bettucci L, Oyhantçabal P, Loureiro J, Ramos VA, Preciozzi F AND BASEI MAS. 2004. Mineralizations of the Lavalleja Group (Uruguay), a probable Neoproterozoic volcano-sedimentary sequence. Gondwana Res 7: 745-751.

SATO K AND KaWAshitA K. 2002. Espectrometria de Massas em Geologia Isotópica. Geol USP Sér Cient 2: 57-77.

Sato K, Siga JR O, Basei MAS, Nutman AP AND SPROESSER W. 2003. Leaching technique and partial digestion using microwave oven: treatment procedures for $\mathrm{U}-\mathrm{Pb}$ dating of metamitic and overgrown zircons. In: South Am Symp Isot Geol, IV, Short Papers, Salvador, Brazil 1: 111-116.

SCHANDL ES, DAVIS DW AND Krogh TE. 1990. Are the alteration halos of massive sulfide deposits syngenetic? Evidence from $\mathrm{U}-\mathrm{Pb}$ dating of hydrothermal rutile at the Kidd volcanic center, Abitibi subprovince, Canada. Geology 18: 505-508.
SCHÄRER U. 1984. The effect of initial ${ }^{230}$ Th disequilibrium on young U-Pb ages: the Makalu case, Himalaya. Earth Planet Sci Lett 67: 191-204.

SCHÄrer U, Xu RH AND Allègre CJ. 1986. U-Th-Pb systematics and ages of Himalayan leucogranites, south Tibet. Earth Planet Sci Lett 77: 35-48.

Scott DJ And St-Onge MR. 1995. Constraints on $\mathrm{Pb}$ closure temperature in titanite based on rocks from the Ungava Orogen, Canada, implications for U-Pb geochronology and P-T-t path determinations. Geology 23: 1123-1126.

SIMPSON RL, PARRISH RR, SEARLE MP AND WATERS DJ. 2000. Two episodes of monazite crystallization during metamorphism and crustal melting in the Everest region of the Nepalese Himalaya. Geology 28: 403-406.

SPEAR FS AND PARRISH RR. 1996. Petrology and cooling rates of the Valhalla complex, British Columbia, Canada. J Petrol 37: 733-765.

STEIGER RH AND JÄGER E. 1977. Subcomission on geochronology: convention on the use of decay constants in geo and cosmochronology. Earth Plan Sci Lett 36: 359362.

SUZUKI K, ADACHI M AND KAJIZUKA I. 1994. Electron microprobe observations of $\mathrm{Pb}$ diffusion in metamorphosed detrital monazites. Earth Planet Sci Lett 128: 391-405.

Timmermann H, Stedrá V, Gerdes A, Noble SR, PARRISH RR AND DÖRR W. 2004. The problem of dating high-pressure metamorphism: a U-Pb isotope and geochemical study on eclogites and related rocks of the Mariánské Lázne Complex, Czech Republic. J Petrol 45: 1311-1338.

UNRUG R. 1997. Rodinia to Gondwana: the geodynamic map of Gondwana supercontinent assembly. Geol Soc Amer Today 7: 1-6.

VArela R, BAsei MAS, Cingolani CA, Siga JR O AND PASSARELli CR. 2005. El basamento cristalino de los andes norpatagónicos en Argentina: Geocronología e interpretación tectônica. Rev Geol Chile 32: 167-187.

VAVRA G. 1990. On the kinematics of zircon growth and its petrogenetic significance: a cathodoluminescence study. Contrib Mineral Petrol 106: 90-99.

VAVRA G, SCHMID R AND GEBAUER D. 1999. Internal morphology, habit and U-Th-Pb microanalysis of amphiboliteto-granulite facies zircons: geochronology of the Ivrea Zone (Southern Alps). Contrib Mineral Petrol 134: 380404. 
VRY JK AND BAKER JA. 2006. LA-MC-ICPMS Pb-Pb dating of rutile from slowly cooled granulites: Confirmation of the high closure temperature for $\mathrm{Pb}$ diffusion in rutile. Geochim Cosmochim Acta 70: 1807-1820.

WetheriLl GW. 1956. Discordant uranium lead ages. Trans Amer Geophys Union 37: 320-326.

Wong L, DAVIS DW, KRogh TE AND Robert F. 1991. U$\mathrm{Pb}$ zircon and rutile geochronology of Archean greenstone formation and gold mineralization in the Val d'Or region, Quebec. Earth Planet Sci Lett 104: 325-336.
ZHANG LS AND SCHÄRER U. 1996. Inherited Pb components in magmatic titanite and their consequence for the interpretation of $\mathrm{U}-\mathrm{Pb}$ ages. Earth Planet Sci Lett 138: 57-65.

ZHU XK, O'NiOns RK, BELSHAw NS ANd GiBB AJ. 1997. Significance of in situ SIMS chronometry of zoned monazite from the Lewisian granulites, northwest Scotland. Chem Geol 135: 35-53. 